\title{
Regulation by Settlement
}

\author{
Matthew C. Turk*
}

\section{INTRODUCTION}

Despite its institutional sprawl and legal complexity, the modern administrative state is commonly understood to reflect a single, central balancing act. On the one hand, agencies are granted vast policymaking discretion in deference to their superior subject matter expertise. On the other hand, that delegation is simultaneously cabined by a thicket of procedural constraints, intended to serve as safeguards against arbitrary or opportunistic decision-making. ${ }^{1}$ The end product is regulation that emerges from a "very elaborate, inclusive, deliberate, multi[-]staged, heavily lawyered decision[-]making process." Rather than rehash the merits of this standard model, public law scholarship increasingly seeks to uncover pockets of administrative "unorthodoxy," where the typical checks on agency action fall away. ${ }^{3}$ A classic example concerns executive inaction, where the President's judgment to not enforce the law cannot be second-guessed by other political actors. ${ }^{4}$ Another paradigm case involves regulation during periods of emergency, which tend to empower agencies

* Assistant Professor of Business Law, Indiana University - Kelley School of Business. I am grateful for helpful comments from the following: Rachel Brewster, Dan Cahoy, Gideon Mark, Mark Mendelsohn, Geoffrey Miller, Susan Rose-Ackerman, Cindy Schipani, Steven Davidoff Solomon, Andrew Spalding, Paul Stephan, Matthew Stephenson, Pierre-Hugues Verdier, Andy Vollmer, and David Zaring, along with other participants at the National Business Law Scholars Conference, Big Ten Business Law Research Seminar, and University of Virginia School of Law's Sokol Colloquium. For excellent research assistance, I would like to thank Jarod Zimmerman, Indiana University Maurer School of Law.

1. See generally Lisa Schultz Bressman, Procedures as Politics in Administrative Law, 107 Colum. L. REV. 1749 (2007); Richard B. Stewart, The Reformation of American Administrative Law, 88 HARV. L. REV. 1669 (1975).

2. Thomas W. Merrill, A Comment on Metzger and Zaring: The Quicksilver Problem, 78 L.\& CONTEMP. Probs., no. 3, 2015, at 189, 190.

3. See, e.g., Daniel A. Farber \& Anne Joseph O'Connell, The Lost World of Administrative Law, 92 TeX. L. ReV. 1137 (2014); Abbe R. Gluck, Anne Joseph O'Connell \& Rosa Po, Unorthodox Lawmaking, Unorthodox Rulemaking, 115 COLUM. L. REV. 1789 (2015).

4. See Lisa Schultz Bressman, Judicial Review of Agency Inaction: An Arbitrariness Approach, 79 N.Y.U. L. REV. 1657, 1659-60 (2004); Daniel T. Deacon, Deregulation Through Nonenforcement, 85 N.Y.U. L. Rev. 795, 796-98 (2010); Jeffrey A. Love \& Arpit K. Garg, Presidential Inaction and the Separation of Powers, 112 MicH. L. REV. 1195, 1197-99 (2014). 
to seize the policy agenda in a relatively unfettered manner. ${ }^{5}$ The recent financial crisis proved fertile ground for emergency regulation and, according to one influential account, freed agencies to adopt highly informal crisis management tactics that amounted to a regime of "regulation by deal."

While emergency interventions such as regulation by deal are by definition temporary, this article identifies a new form of administrative unorthodoxy- "regulation by settlement" - that is reshaping the day-today status quo of financial regulation and may be here to stay. Regulation by settlement refers to a practice that has emerged from recent changes in the regulatory enforcement environment, which include an increased emphasis on corporate (rather than individual) liability, skyrocketing monetary penalties, and the nearly exclusive imposition of those penalties via innovative legal instruments that facilitate out-of-court settlement. Regulation by settlement has two defining features. First, although regulatory settlements are nominally packaged in the form of particularized adversarial disputes, agencies now leverage those agreements in a manner that effectively establishes new legal standards of general applicability. They are a tool for setting policy. Second, the procedural posture of those settlements allows agencies to engage in a uniquely freewheeling mode of regulation, which sidesteps nearly all of the legal constraints that are familiar to the standard administrative model.

To make these conceptual points more concrete, this article presents three case studies that illustrate how regulation by settlement operates in practice. ${ }^{7}$ In each case, the basic pattern is a series of settlements that are negotiated in rapid succession, involve fines reaching into the billions of

5. See generally Eric A. Posner \& Adrian Vermeule, The Executive Unbound: After THE Madisonian RePUblic (2011); Adrian Vermeule, Our Schmittian Administrative Law, 122 HARV. L. REV. 1095 (2009).

6. Steven M. Davidoff \& David Zaring, Regulation by Deal: The Government's Response to the Financial Crisis, 61 ADMIN. L. REV. 463, 468 (2009) (explaining that regulation by deal "reject[ed] some of the usual values of administrative law, such as predecision notice to affected parties and the public; measured, unhasty action; and comment-ventilated policymaking"); see also Eric A. Posner \& Adrian Vermeule, Crisis Governance in the Administrative State: 9/11 and the Financial Meltdown of 2008, 76 U. CHI. L. REV. 1613, 1624 (2010) ("The initial response [to the financial crisis] was a series of ad hoc transactions and measures designed to prop up failing firms"); $c f$. Steven Davidoff Solomon \& David T. Zaring. The Dealmaking State: Executive Power in the Trump Administration (Univ. of Cal. Berkeley Pub. Law \& Legal Theory Research Paper Series, Paper No. 2921407, 2017) (extending the regulation by deal analogy to public-private investment initiatives that have been proposed under the Trump administration), https://papers.ssrn.com/sol3/papers.cfm?abstract_ $\mathrm{id}=2921407 \#$.

7. See infra Section II.B (covering the "FCPA Settlements," the "Securitization Settlements," and the "Benchmark Manipulation Settlements"); see also infra Section II.C (noting a number of further examples). 
dollars, and target certain areas of the financial system on a comprehensive basis. Imposing penalties on such a scale carries a precedential effect that allows agencies to establish general rules-of-the-road going forward. ${ }^{8}$ Importantly, those rules redefine the contours of substantive policy because the settlements at issue do not closely track pre-established legal obligations. Instead, they tend to be premised on novel theories of liability that involve aggressive statutory interpretation or otherwise draw on background legal materials in a creative fashion. ${ }^{9}$ In the process, federal agencies have wielded regulatory settlements in a way that reshapes the governance of the financial system to a degree that goes far beyond traditional notions of prosecutorial discretion.

The informality of regulation by settlement enables agencies to dictate policy unencumbered from the legal constraints that apply to notice-andcomment rulemaking, which is the "dominant procedural vehicle for agency lawmaking." 10 When engaging in rulemaking, agencies must follow protocols set out by the Administrative Procedure Act (APA), which subject their policy judgments to extensive public scrutiny before being finalized. ${ }^{11}$ In stark contrast, the negotiation of agency settlements is a confidential affair, concluded with a handshake in Washington conference rooms. ${ }^{12}$ Regulatory settlements are also immune from most forms of centralized executive branch review, including cost-benefit analysis requirements and other rigors that have become synonymous with "Presidential Administration."13 Finally, once promulgated,

8. Of course, the "regulation" that results is implicit and does not have the force of law in any traditional or technical sense. But that is of limited real-world significance to the market actors that act in its shadow, who as a practical matter must adopt the realist position that "the law is what regulators will do." Cf. Oliver Wendell Holmes, Jr., The Path of the Law, 10 HARV. L. REV. 457, 46061 (1897) ("The prophecies of what the courts will do in fact, and nothing more pretentious, are what I mean by the law.”).

9. Regulation by settlement is therefore distinct from related analyses that focus on the influence that remedial terms in DOJ settlement agreements have on corporate compliance procedures. See generally Jennifer Arlen \& Marcel Kahan, Corporate Governance Regulation Through Nonprosecution, 84 U. CHI. L. REV. 323 (2017); Lawrence A. Cunningham, Deferred Prosecutions and Corporate Governance: An Integrated Approach to Investigation and Reform, 66 FLA. L. REV. 1 (2014); Brandon L. Garrett, Structural Reform Prosecution, 93 VA. L. REV. 853 (2007).

10. Richard B. Stewart, Administrative Law in the Twenty-First Century, 78 N.Y.U. L. REV. 437, 444 (2003). The prominent role of notice-and-comment rulemaking is especially evident in financial regulation, where it is a cornerstone of the Dodd Frank Act. Dodd-Frank Wall Street Reform and Consumer Protection Act, Pub. L. No. 111-203, 124 Stat. 1376 (2010).

11. See Administrative Procedure Act, Pub. L. No. 79-404, 60 Stat. 237 (1946) [hereinafter APA] (codified as amended in scattered sections of 5 U.S.C. $§ 500$ et seq.).

12. Stewart, supra note 1, at 1687 (observing that "the quiet settlement of litigation once initiated ... take[s] place through informal procedures where the traditional controls have not normally applied").

13. See Elena Kagan, Presidential Administration, 114 HARv. L. Rev. 2245, 2246 (2001); 
administrative rules may be scrutinized pursuant to the "hard look" standard applied by federal courts. The bargains struck in regulatory settlements, meanwhile, are memorialized with out-of-court legal instruments that are susceptible to little or no judicial review.

Here, administrative law specialists will interject with the Chenery principle, which holds that agencies have discretion to conduct policymaking through any procedural vehicle available, including adjudicative hearings and informal statements such as guidance documents. ${ }^{14}$ Securities law experts will likewise point to the SEC's alleged use of "regulation by enforcement" to develop insider trading law. ${ }^{15}$ The most striking quality of regulation by settlement, however, is that it allows agencies to avert two pervasive tradeoffs that accompany the decision to switch from notice-and-comment rulemaking to take advantage of less formal policymaking venues. The first is a "formalityreview" tradeoff, in which agencies tend to receive more deferential judicial review in exchange for adopting more formal procedures. ${ }^{16}$ Agencies face a "substance-discretion" tradeoff as well. In general, regulators must invest in greater procedural formality when making decisions that push the substantive boundaries of policy in bolder directions. ${ }^{17}$ Yet unlike most other informal modes of agency action, regulation by settlement simultaneously circumvents both tradeoffs, by combining aggressive substantive policymaking with maximal procedural laxness and minimal ex post review.

Although the primary purpose of this article is to present a positive analysis of regulation by settlement, it closes by considering normative issues as well as potential policy reforms. The rise of regulatory settlements has been viewed as in tension with traditional rule of law values. As this article will argue, however, many of these concerns are misplaced. ${ }^{18}$ From a less legalistic and more consequentialist perspective, it is clear that regulation by settlement carries costs as well as benefits. Its primary benefit is to invest agencies with greater flexibility, by allowing

Lawrence Lessig \& Cass R. Sunstein, The President and the Administration, 94 Colum. L. Rev. 1, 102-03 (1994).

14. See SEC v. Chenery Corp., 332 U.S. 194, 208-09 (1947) (Chenery II).

15. See Harvey L. Pitt \& Karen L. Shapiro, Securities Regulation by Enforcement: A Look Ahead at the Next Decade, 7 YALE J. ON REg. 149, 156-57 (1990).

16. See United States v. Mead Corp., 533 U.S. 218, 229-31 (2001); M. Elizabeth Magill, Agency Choice of Policymaking Form, 71 U. CHI. L. REv. 1383, 1431 (2004); Cass R. Sunstein, Chevron Step Zero, 92 VA. L. REV. 187, 213-16 (2006).

17. See Matthew C. Stephenson, The Strategic Substitution Effect: Textual Plausibility, Procedural Formality, and Judicial Review of Agency Statutory Interpretations, 120 HARV. L. REV. 528, 528-29 (2006).

18. See infra Section IV.A. 
regulators to police corporate misconduct in a way that keeps pace with evolving market conditions and the strategic adaptations of firms. At the same time, reliance on settlements necessarily injects ambiguity into the legal standards that govern market activity, and may also encourage agencies to intervene in regulated industries in an uncoordinated or otherwise overly aggressive manner. As the case studies show, the weight of these costs and benefits does not uniformly cut in one direction, and depends on the legal and economic context in which regulation by settlement is applied. A policy upshot is that any reform to agencies' enforcement practices should be incremental and work at the margin. While the main proposals in this area advocate for enhanced judicial scrutiny of regulatory settlements, this article explains that a more promising approach would be to facilitate greater oversight of settlements within the executive hierarchy itself. ${ }^{19}$

The broader contribution of this article is to supply a richer account of the regulatory process by examining its public law and business law aspects in parallel. Although administrative law and financial regulation overlap along prominent historical and institutional dimensions, legal scholarship has displayed a puzzling tendency to consider each in isolation. ${ }^{20}$ Thus, as one commentator has observed, the time is "ripe for sustained and reciprocal engagement between administrative law and financial regulation at both a conceptual and more granular level." ${ }^{21}$ This article takes up both challenges. It first proceeds by adopting a finegrained look at the evolving procedural features of agency enforcement practices, and explains the overlooked ways they have come to influence the substance of financial regulation. It then uses those same developments in financial regulation as a lens to uncover a new and qualitatively distinct mode of regulatory policymaking, thereby advancing the administrative law literature on agency unorthodoxy.

The organization of this article is as follows. Section II approaches regulation by settlement from a business law perspective that analyzes its growing role in the governance of the financial system. Section III turns to the public law implications of regulation by settlement, and explains how it represents a novel mode of unorthodox administrative lawmaking.

19. See infra Section IV.B (identifying administrative mechanisms established under the DoddFrank Act that could be made responsible for new oversight procedures).

20. See, e.g., Robert B. Ahdieh, Notes from the Border: Writing Across the Administrative Law/Financial Regulation Divide, 66 J. LEGAL EDUC. 64, 64 (2016) (finding it "surprising . . . how little has been written across the seemingly thin divide that separates administrative law and financial regulation"); see also Gillian E. Metzger, Through the Looking Glass to a Shared Reflection: The Evolving Relationship Between Administrative Law and Financial Regulation, 78 L. \& CONTEMP. PROBS., no. 3, 2015, at 129, 129.

21. Metzger, supra note 20, at 131. 
Section IV considers normative issues and then reviews potential policy reforms. Section V briefly concludes.

\section{REgUlation By SetTlEMENT \& THE FinANCIAL SYSTEM}

This section explains how federal agencies have reshaped the content of post-crisis financial regulation by settling enforcement actions against firms. Section A identifies key changes in the regulatory landscape that were preconditions for that process to emerge. Section B presents three case studies that illustrate how settlements are used to set policy in practice. Section $\mathrm{C}$ briefly notes further examples and provides a summary.

\section{A. The Rise of Regulatory Settlements}

Regulation by settlement has been made possible by a sweeping transformation in the enforcement practices of administrative agencies responsible for financial regulation and related areas of securities law. The origins of the new enforcement environment can be traced to changes that began in the early 2000s and have developed along four, interrelated fronts. First, where enforcement actions against individuals were once the standard, actions against firms have become the norm. Second, disputes between agencies and firms are now almost exclusively resolved via settlement agreements, rather than adjudication on the merits. Third, the nature of settlements has evolved, due to innovative legal instruments which limit judicial review while also facilitating regulator-firm bargains that incorporate a broader set of terms. Fourth, enforcement actions have resulted in dramatically higher monetary penalties.

Regulatory enforcement efforts directed at malfeasance in financial markets has traditionally targeted individuals rather than firms. A paradigm case is enforcement of insider trading by the SEC, which began in the 1960s and has always overwhelmingly consisted of actions against individuals. ${ }^{22}$ In banking regulation, the 1980 s savings-and-loan crisis resulted in hundreds of criminal convictions of individuals by the DOJ. ${ }^{23}$ Likewise, agencies such as the Commodities Futures Trading Commission

\footnotetext{
22. See James J. Park, Rules, Principles, and the Competition to Enforce the Securities Laws, 100 CAL. L. REV. 115, 150-52 (2012).

23. See Bruce A. Green, After the Fall: The Criminal Law Enforcement Response to the $S \& L$ Crisis, 59 FORDHAM L. REV. S155, S170 n.105 (1991) (providing statistics on financial executives convicted of crimes in connection with S\&L era investigations).
} 
(CFTC) have tended to use their remedial authority to target market professionals with license revocations and modest fines. ${ }^{24}$

Corporate liability started to receive greater emphasis with a pair of guidance documents - the DOJ's Holder Memorandum of 1999 and the SEC's Seaboard Report of 2001 - both of which provided government attorneys with a roadmap for bringing cases specifically against firms. ${ }^{25}$ The shift in enforcement priorities gained traction shortly thereafter, when the dotcom boom collapsed in a wave of accounting fraud and options back-dating scandals. Although that era yielded hundreds of proceedings against corporate managers, high-profile firms such as Enron and WorldCom were found liable as well. ${ }^{26}$ Those successes spurred regulators to further prioritize "[v]igorous enforcement... [against] corporate wrongdoers." ${ }^{27}$ A full swing of the enforcement pendulum from individual to corporate liability was complete following the financial crisis of 2008. As has been widely documented (and frequently criticized), actions against the high-ranking financial executives who were involved in those events have been nearly non-existent relative to historical standards. ${ }^{28}$

24. See Ben Protess, Libor Case Energizes a Wall Street Watchdog, N.Y. Times (Aug. 12, 2012), https://dealbook.nytimes.com/2012/08/12/libor-case-energizes-gensler-and-the-c-f-t-c/?mcub $\mathrm{z}=0$.

25. Report of Investigation Pursuant to Section 21(a) of the Securities Exchange Act of 1934 and Commission Statement on the Relationship of Cooperation to Agency Enforcement Decisions, Securities Act Release No. 44969, 76 SEC Docket 220 (Oct. 23, 2001); Memorandum from Eric Holder, Deputy Attorney Gen., Dep't of Justice, on Bringing Criminal Charges Against Corporations to All Component Heads \& U.S. Attorneys (June 16, 1999) [hereinafter Holder Memorandum], https://www.justice.gov/sites/default/files/criminal-fraud/legacy/2012/12/03/response2-appx-k.pdf.

26. See Peter Lattman, Looking at Ken Lay and the Lack of Financial Crisis Cases, N.Y. TIMES (July 5, 2011), https://dealbook.nytimes.com/2011/07/05/looking-at-ken-lay-and-the-lack-offinancial-crisis-cases/ (reporting that dot-com-era enforcement resulted in "1,300 corporate fraud convictions, including cases against more than 200 [high-ranking executives]"); see also Stephen J. Choi, Anat Carmy Wiechman \& Adam C. Pritchard, Scandal Enforcement at the SEC: The Arc of the Option Backdating Investigations, 15 AM. L. \& ECON. REV. 542 (2013).

27. Memorandum from Larry D. Thompson, Deputy Attorney Gen., Dep't. of Justice, on Principles of Federal Prosecution of Business Organizations to Heads of Dep't Components \& U.S. Attorneys (Jan. 20, 2003) [hereinafter Thompson Memorandum], https://www.americanbar.org/ content/dam/aba/migrated/poladv/priorities/privilegewaiver/2003jan20_privwaiv_dojthomp.authche ckdam.pdf.

28. See David Zaring, Litigating the Financial Crisis, 100 VA. L. REV. 1405, 1410-11 (2014) (noting the "surprising dearth of individual penalties" coming out of the financial crisis); see also Jed S. Rakoff, The Financial Crisis: Why Have No High-Level Executives Been Prosecuted?, N.Y. Rev. BooKs (Jan. 9, 2014), http://www.nybooks.com/articles/2014/01/09/financial-crisis-why-noexecutive-prosecutions/; Two Financial Crises Compared: The Savings and Loan Debacle and the Mortgage Mess, N.Y. TIMES (Apr. 13, 2011), http://www.nytimes.com/interactive/2011/04/14/ business/20110414-prosecute.html?mcubz $=0$ (comparing the response to the savings and loan crisis and the recent financial crisis). 
While settlement of regulatory actions has always been commonplace, it became a predetermined outcome following the dotcom-era enforcements. The proximate cause was a jury trial of Enron's auditor, the accounting firm Arthur Andersen, which ended in a criminal conviction that immediately drove the company into bankruptcy. The Arthur Andersen episode gave rise to the perception that findings of criminal liability amounted to a "corporate death penalty," due to the costly collateral consequences that firms could expect to encounter as a result. ${ }^{29}$ Risk-averse firms reacted by becoming even more avoidant of bet-the-company litigation, regardless of the underlying merits. ${ }^{30}$ The government also expressed unease with the Arthur Andersen episodes and acknowledged the unfairness that corporate penalties carried for otherwise innocent shareholders and employees. ${ }^{31}$ Thus, the demand for settlement increased for all parties involved.

Supply rose to meet demand once the DOJ began to offer firms the option of resolving enforcement actions pursuant to previously esoteric legal instruments - known as deferred prosecution agreements (DPAs) and non-prosecution agreements (NPAs) (collectively, pretrial diversion agreements (PDAs)). ${ }^{32}$ Those agreements had innovative features that made settlement even more attractive for both sides. Firms benefited from PDAs because they allow defendants to not only escape trial, but also avoid the collateral consequences associated with admissions of wrongdoing, which are by definition required in traditional guilty pleas. ${ }^{33}$

29. Gabriel Markoff, Arthur Andersen and the Myth of the Corporate Death Penalty: Corporate Criminal Convictions in the Twenty-First Century, 15 U. PA. J. BuS. L. 797, 800 (2013). Collateral consequences include reputational harm in the marketplace, bans on eligibility for government contracting, and follow-on shareholder class actions. See Cunningham, supra note 9, at 6-7, 20-25.

30. Cunningham, supra note 9, at 14. Arthur Andersen was ruined despite ultimately prevailing on the merits. Four years after the firm's bankruptcy, a 9-0 Supreme Court decision vacated its conviction on all counts. Arthur Andersen LLP v. United States, 544 U.S. 696, 696-97 (2005); See also Markoff, supra note 29, 804-05 (describing the demise of Arthur Andersen).

31. See generally Thompson Memorandum, supra note 27 (stating this concern); see also Lanny A. Breuer, Assistant Attorney Gen., Speech at the New York City Bar Association (Sept. 13, 2012) https://www.justice.gov/opa/speech/assistant-attorney-general-lanny-breuer-speaks-new-york-citybar-association ("In reaching every charging decision, we must take into account the effect of an indictment on innocent employees and shareholders, just as we must take into account the nature of the crimes committed and the pervasiveness of the misconduct.").

32. Garrett, supra note 9, at 887-900 (describing the DOJ development and increase in use of PDAs). With a DPA, a prosecutor files a criminal charge (or criminal information) in court but agrees to defer any actual prosecution if the defendant satisfies certain terms and conditions. Under an NPA, a prosecutor agrees not to file a charging document at all in return for a firm's commitment to certain conditions. NPAs are therefore memorialized in the form of a letter, rather than a court document. Garrett, supra note 9, at 938 (appendix detailing the main features of DPAs and NPAs).

33. See Memorandum from Mark Filip, Deputy Att'y Gen., Dep't of Justice, on Principles of Federal Prosecution of Business Organizations to Heads of Dep't Components \& U.S. Attorneys 18- 
Because they are subject to little or no judicial review, PDAs provided the government with a valuable new low-risk, low-cost dispute resolution vehicle. ${ }^{34}$ The DOJ also took advantage of the informal, out-of-court nature of PDAs to introduce novel settlement terms - which require firms to reform internal compliance procedures and to install corporate "monitors" who are authorized to supervise the performance of those initiatives - that made detection and punishment of recidivism a foregone conclusion. ${ }^{35}$ Lastly, for the very reason that firms preferred PDAs to guilty pleas, they gave the government leverage to extract larger penalties. $^{36}$

The DOJ almost never offered pretrial diversion agreements prior to 2003, but their use has since exploded, and PDAs now represent the DOJ's primary legal mechanism for concluding actions against high-profile corporate defendants. ${ }^{37}$ The novel legal format of settlement agreements has not been limited to criminal enforcement. During the same post-2003 period, the SEC has adapted its use of civil settlement instruments, such as cease-and-desist orders, to mimic the out-of-court posture, enhanced monetary penalties, and broad remedial terms of PDAs. ${ }^{38}$ After the

20 (Aug. 28, 2008), https://www.justice.gov/sites/default/files/dag/legacy/2008/11/03/dag-memo08282008.pdf (providing a relatively unconditional embrace of reliance on PDAs).

34. See infra notes 204-14 and accompanying text (reviewing the case law on judicial review of PDAs).

35. See Cunningham, supra note 9 , at 10-15.

36. See id. at $15-20$.

37. Before 2003, the DOJ had entered into fewer than 30 DPAs. Since then, however, it has concluded over 300. The use of NPAs has followed a parallel trajectory. See Cunningham, supra note 9, at 14; Client Alert: 2015 Year-End Update on Corporate Non-Prosecution Agreements (NPAs) and Deferred Prosecution Agreements (DPAs), GiBSON DuNN \& CRUTCHER LLP (Jan. 5, 2016), [hereinafter Gibson Dunn Client Alert], http://www.gibsondunn.com/publications/documents/2015Year-End-Update-Corporate-Non-Prosecution-Agreements-and-Deferred-ProsecutionAgreements.pdf; see also Brandon L. Garrett \& David Zaring, For a Better Way to Prosecute Corporations, Look Overseas, N.Y. TIMES (Sept. 23, 2013, 3:43 PM), https://dealbook.nytimes.com/2013/09/23/for-a-better-way-to-prosecute-corporations-lookoverseas $/$ mcubz $=0$ (noting over $60 \%$ of DPAs are with public corporations and almost $33 \%$ involve Fortune 500 or Global 500 companies).

38. Like DPAs, the SEC files civil settlements in federal court on the same day that it enters a complaint, and thereby preempts litigation on the merits. Since 2010, the SEC has begun to follow the DOJ by employing DPAs and NPAs itself. Press Release, Robert Khuzami, Director, SEC, SEC Announces Initiative to Encourage Individuals and Companies to Cooperate and Assist in Investigations (Jan. 13, 2010), https://www.sec.gov/news/press/2010/2010-6.htm. The SEC has also made an end-run around its relatively modest civil fining authority, by relying on equitable remedies, such as disgorgement, which can exceed standard monetary penalties by multiple orders of magnitude. See Paul S. Atkins \& Bradley J. Bondi, Evaluating the Mission: A Critical Review of the History and Evolution of the SEC Enforcement Program, 13 FORDHAM J. CORP. \& FIN. L. 367, 399 (2008) (arguing that the SEC has shifted to a "punitive" enforcement model during its current "[e]ra of [i]ncreasing [p]enalties against [s]hareholders"). 
financial crisis, the same basic settlement procedures have been adopted with equal vigor by the full gamut of federal financial agencies. ${ }^{39}$

The new breed of corporate settlements has been associated with dollar penalties that would have been unfathomable in previous enforcement eras. Over the first dozen years of their existence, PDAs have been associated with total monetary penalties of over $\$ 40$ billion. $^{40}$ Corporate penalties imposed by the DOJ-the majority of which are now paid by financial institutions - rose steadily for ten consecutive years, culminating with more than $\$ 22$ billion paid from 2001 to 2015 by financial institutions. ${ }^{41}$ A $\$ 550$ million settlement between the SEC and Goldman Sachs in 2010 was hailed at the time as the "largest-ever penalty paid by a Wall Street firm." "42 But within two years, that record was beaten by a factor of thirty when Bank of America entered into a multi-agency settlements for $\$ 16.6$ billion. ${ }^{43}$ These trends are not attributable to a few outlier agencies. Financial regulators that have a prior track record of extracting significant corporate fines - such as the Federal Reserve Board, Office of the Comptroller of Currency (OCC) or CFTC - now regularly impose penalties that reach into the billions per year. ${ }^{44}$

39. See John F. Savarese \& Wayne M. Carlin, White Collar and Regulatory Enforcement Trends in 2014, Harv. L. SCH. F. ON CORP. GOvernanCE \& Fin. Reg. (Jan. 28, 2014), https://corpgov.law.harvard.edu/2014/01/28/white-collar-and-regulatory-enforcement-trends-in-

2014/ ("Other government regulators also continue to be active in the civil enforcement areas. In addition to the SEC, which has long made aggressive use of its civil enforcement power, other agencies such as the CFTC, the newly-formed CFPB and bank regulators, such as the OCC and the Federal Reserve, have become much more aggressive in seeking civil enforcement remedies and penalties.”).

40. See Gibson Dunn Client Alert, supra note 37.

41. Brandon L. Garrett, The Rise of Bank Prosecutions, 126 YALE L.J.F. 33, 36 (2016), $\mathrm{http} / / /$ www.yalelawjournal.org/forum/the-rise-of-bank-prosecutions. Specifically, the amount paid by financial institutions increased from zero in 2001 to almost seven billion in 2015. See id.

42. Goldman, Sachs \& Co., Litigation Release No. 21592, 98 SEC Docket 3135, 2010 WL 2799362 (July 15, 2010). Compare a 2002 settlement with Xerox, in which "the SEC obtained its first $\$ 10$ million [enforcement] penalty" against a securities issuer. Atkins \& Bondi, supra note 38.

43. All told, regulatory enforcement actions against banks for securitization practices has been estimated to have resulted in $\$ 110$ billion in penalties. Christina Rexrod \& Emily Glazer, Big Banks Paid \$110 Billion in Mortgage-Related Fines. Where Did the Money Go?, WALL ST. J. (Mar. 9, 2016), https://www.wsj.com/articles/big-banks-paid-110-billionin-mortgage-related-fines-where-did-themoney-go-1457557442.

44. In 2014 alone, enforcement actions by the CFTC reportedly resulted in $\$ 3.14$ billion in civil penalties. Press Release, U.S. Commodities Futures Trading Comm'n, CFTC Releases Annual Enforcement Results for Fiscal Year 2015 (Nov. 6, 2015), http://www.cftc.gov/PressRoom/PressReleases/pr7274-15 [hereinafter CFTC Annual Enforcement Results, Fiscal Year 2015]. Although some commentators argue that agencies are inflating these figures, no amount of rounding up alters the picture of a massive rise in the severity of penalties over recent years. See, e.g., Urska Velikonja, Reporting Agency Performance: Behind the SEC's Enforcement Statistics, 101 CORNELL L. REV. 901 (2016) (describing flaws in the SEC's reported statistics). 
Each of the developments summarized above have been noted in the business law literature, but typically in a piecemeal fashion that focuses on particular agencies, settlement instruments, or legal prohibitions. Such an approach obscures the striking fact that all four trends have taken place on a roughly contemporaneous basis, across every agency with jurisdiction over financial institutions, and in the context of both criminal and civil corporate liability. To a large extent, regulators at the OCC now wield settlement instruments such as consent orders in a manner that is functionally indistinguishable from the use of DPAs by DOJ prosecutors. ${ }^{45}$ An implication is that there has been a reorientation of the relationship between the financial system and the administrative state as a whole, with regulatory settlements now occupying a central role. As a result, agencies are able to leverage those agreements in a manner that reshapes policy to a degree that goes far beyond traditional notions of prosecutorial discretion or "regulation by enforcement." 46

\section{B. Three Case Studies}

The following three case studies illustrate how regulation by settlement works in practice. The first case involves enforcement of anticorruption prohibitions in securities law pursuant to the Foreign Corrupt Practices Act (FCPA). Although the FCPA Settlements do not concern "financial regulation" narrowly understood, they are an important precursor and blueprint for agency practices that have subsequently been applied more broadly in financial regulation. The second case study looks at settlements arising from agency actions against the issuance of mortgage-backed securities by large banks that were at the heart of the financial crisis (the Securitization Settlements). The Securitization Settlements reveal that a major component of post-financial crisis regulation has been dictated informally through settlements, rather than the regime installed under the Dodd-Frank Act. The third case examines

\footnotetext{
45. See infra Section II.B.ii (analyzing the parallel application of those agreements to the same underlying conduct). Legal scholarship has at times sketched a rough analogy between criminal prosecution and administrative enforcement, but as the case studies below will show, regulation by settlement goes much further and completely collapses any meaningful distinction between "white collar crime" and regulatory enforcement. See, e.g., Rachel E. Barkow, Institutional Design and the Policing of Prosecutors: Lessons from Administrative Law, 61 STAN. L. REV. 869 (2009) (drawing on the administrative law-prosecution analogy); Dan M. Kahan, Is Chevron Relevant to Federal Criminal Law?, 110 HaRV. L. Rev. 469, 470 (1996); Gerard E. Lynch, The Role of Criminal Law in Policing Corporate Misconduct, 60 L. \& CONTEMP. PROBS., No. 3, 1997, at 23, 23 (drawing on the administrative law-prosecution analogy).

46. See infra Section III.B.iii (comparing regulation by settlement to previous forms of administrative enforcement).
} 
a line of settlements in connection with financial benchmarks such as the Libor index (the Benchmark Settlements). The Benchmark Settlements provide a case in which regulation by settlement has been applied to critical areas of the financial sector which were not directly related to the financial crisis.

\section{The FCPA Settlements}

Congress passed the FCPA in $1977,{ }^{47}$ in response to a series of corporate corruption scandals that were uncovered during the Watergate investigation. ${ }^{48}$ The core of the statute is its "anti-bribery provisions," which prohibit entities or individuals from making improper payments to foreign governments in order to gain a business advantage. ${ }^{49}$ In addition, the FCPA has "books-and-records" and "internal controls" provisions, which require that corporate accounting procedures are reasonably designed to detect or deter potentially illicit payments. ${ }^{50}$ The law is jointly enforced by the DOJ and SEC. ${ }^{51}$

The FCPA's enforcement history is a microcosm of the system-wide enforcement trends reviewed above. From the date of its passage until the early 2000 s, the statute was a legal curio that was rarely used. ${ }^{52}$ Since that initial quiet period, however, enforcement efforts at both the DOJ and SEC have rapidly accelerated. ${ }^{53}$ The rise of FCPA enforcement has paralleled the broader shift in focus from individual to corporate liability. It also tracks the turn toward settlement as the exclusive mode of dispute resolution, including the abandonment of traditional guilty pleas in favor of pretrial diversion agreements. ${ }^{54}$ Lastly, the relatively modest fines

\footnotetext{
47. Foreign Corrupt Practices Act of 1977, 15 U.S.C. $\S \S 78 \mathrm{dd}-1-3,78 \mathrm{ff}, 78 \mathrm{~m}$ (2012).

48. SEC, Report of the SeCurities and EXChANGe Commission on Questionable and ILLEGAL CORPORATE PAYMENTS AND PRACTICES 2 (1976).

49. 15 U.S.C. $\S 78 d d-1(a)$.

50. $I d$. at $\S 78 \mathrm{~m}(\mathrm{~b})$.

51. The DOJ has authority to pursue criminal penalties, while the SEC can impose fines and disgorgement of profits in connection with civil liability. See U.S. Dep't of Justice \& Sec. \& Exch. Comm'n, A Resource Guide to the U.S. Foreign Corrupt Practices Act, U.S. DeP'T OF JustiCE (Jan. 16, 2015) [hereinafter FCPA Guidance], https://www.justice.gov/sites/default/files/criminalfraud/legacy/2015/01/16/guide.pdf.

52. The DOJ only prosecuted 25 FCPA actions against corporations for the entire 1977-1998 period. See Michael B. Bixby, The Lion Awakens: The Foreign Corrupt Practices Act-1977 to 2010, 12 SAN DIEGO INT'L L.J. 89, 103 (2010).

53. See id. at 104-05 (describing the increase in FCPA actions "the current post-Enron, Sarbanes-Oxley Act (SOX) era").

54. See Mike Koehler, Measuring the Impact of Non-Prosecution and Deferred Prosecution Agreements on Foreign Corrupt Practices Act Enforcement, 49 U.C. DAVIS L. REV. 497, 497-98 (2015) [hereinafter Koehler, Foreign Corrupt Practices Act Enforcement].
} 
which characterized the FCPA's quiet period have given way to a boomera of skyrocketing penalties that now reach into the billions per year. ${ }^{55}$

What is the legal basis underlying the sudden surge in corporate FCPA liability? A precise answer is surprisingly difficult to pin down by reference to the standard legal sources. Congress expressed core elements of the law with vague language that cries out for further clarification: a bribe consists of an offer to "corruptly" provide "anything of value" to a "foreign official" in order to "obtain[] or retain[] business." available legislative history, but it has been subject to neglect, and reflects a Nixonian, Cold War milieu that is of uncertain applicability to the contemporary global business environment. ${ }^{57}$ Case law is of limited help as well. Because the FCPA enforcement boom has been concurrent with the rise of regulatory settlements, federal courts have had minimal opportunities to flesh out the meaning of important yet ambiguous statutory terms. ${ }^{58}$ In fact, only one corporate defendant has ever taken FCPA-related charges to trial, and that was a 1983 case from the FCPA's pre-modern era. ${ }^{59}$ The enforcement agencies, for their part, have done little to fill the resulting interpretive void. There is an FCPA "Opinion Procedure," established by statutory amendments in 1988, but it only allows the agencies to respond to hypothetical scenarios that are volunteered by firms, and is rarely utilized. ${ }^{60}$ And, with the exception of a guidance document issued in 2012 (to be discussed below), the only other agency interpretative materials that have been released are a pair of rules issued by the SEC in $1979 .{ }^{61}$

55. The DOJ has collected roughly $\$ 3$ billion since 2010. See id. at 522 n.63.

56. 15 U.S.C. $\S 78 \mathrm{dd}-1$ (a) (2012). See James R. Doty, Toward a Reg. FCPA: A Modest Proposal for Change in Administering the Foreign Corrupt Practices Act, 62 Bus. LAW. 1233, 1239 (2007) ("Vagueness and ambiguity are the DNA of the FCPA ....").

57. See generally Mike Koehler, The Story of the Foreign Corrupt Practices Act, 73 OHIO ST. L.J. 929 (2012).

58. United States v. Kozeny, 493 F. Supp. 2d 693, 697 (S.D.N.Y. 2007) (noting that there are "surprisingly few decisions throughout the country on the FCPA").

59. SEC v. World-Wide Coin Invs., Ltd., 567 F. Supp. 724 (N.D. Ga. 1983). Since 2004, only two of the DOJ's FCPA actions have even progressed to criminal indictments, and both of those were dismissed: Lindsey Manufacturing Co. and Cinergy Telecomm'ns Inc. See United States v. Aguilar, 831 F. Supp. 2d 1180 (C.D. Cal. 2011) ("throw[ing] out the convictions of Defendants Lindsey Manufacturing Company, Keith E. Lindsey and Steve K. Lee and dismiss[ing] the First Superseding Indictment"); Case Information, Stan. L. Sch. Foreign Corrupt PraCs. ACt Clearinghouse, http://fcpa.stanford.edu/enforcement-action.html?id=264 (last visited Oct. 22, 2017) (charges against Cinergy Telecommunications, Inc. dismissed on February 24, 2012).

60. See Matthew W. Muma, Toward Greater Guidance: Reforming the Definitions of the Foreign Corrupt Practices Act, 112 MicH. L. REV. 1337, 1344 (2014) (“Unfortunately, [Opinion Releases] are scarce, slow in coming, and highly general").

61. 17 C.F.R. $\S \S 240.13 b 2-1$ to -2 . 
Accordingly, when corporate counsel prepare to advise their clients on FCPA liability, they do not linger over the statute, regulatory materials, or judicial opinions. Instead, they consult online databases that summarize prior settlements, and attempt to extract a general rule that will predict future enforcement practices. $^{62}$ Because FCPA settlements have repeatedly centered around particular industries, business practices, or statutory terms, certain implicit legal standards governing anti-corruption law have in fact emerged. ${ }^{63}$ Notably, the dominant pattern is for those standards to take the pre-existing legal materials in broad and creative directions.

One example is the FCPA's requirement that it must be a "foreign official" who receives the bribe in order for liability to be triggered under the Act. ${ }^{64}$ One possibility - consistent with the circumstances surrounding the FCPA's passage, as well the first two decades of its enforcement-is that such a category is limited to high-ranking government representatives. ${ }^{65}$ But a string of boom-era settlements has established a much more capacious definition. Pursuant to those precedents, the "foreign official" label applies not only to low-ranking bureaucrats, but also covers employees of private companies, such as medical personnel at hospitals, in which the government has a partial (in some case only minority) ownership stake. ${ }^{66}$ Because a good deal of investment takes place in developing economies where the line between private and public

62. See Philip Urofsky \& Danforth Newcomb, FCPA Digest: Recent Trends and Patterns in the Enforcement of the Foreign Corrupt Practices Act, SHEARMAN \& STERLING LLP (July 5, 2017), http://www.shearman.com/ /media/Files/NewsInsights/Publications/2017/07/Shearman--SterlingsRecent-Trends-and-Patterns-in-the-Enforcement-of-t.pdf.

63. Foreign Corrupt Practices Act: Hearing Before the Subcomm. on Crime, Terrorism, \& Homeland Sec. of the H. Comm. on the Judiciary, 112th Cong. 22 (2011) (statement of Michael Mukasey) ("The primary statutory interpretive function therefore is performed almost exclusively by the DOJ Fraud Section and the SEC, which are responsible for bringing FCPA charges. By negotiating resolutions in many cases before an indictment or enforcement action is filed ... [w]e are left with a circumstance in which ... 'the FCPA means what the enforcement agencies say it means."').

64. 15 U.S.C. $\S 78 d d-1$ (f) (2012). The statute further provides that a "foreign official" may consist of a government "department," "agency," or "instrumentality." Id.

65. See From SOE Employees to Health Care Providers - The "Foreign Officials" of 2012, FCPA PROFESSOR BLOG (Jan. 10, 2013), http://fcpaprofessor.com/from-soe-employees-to-healthcare-providers-the-foreign-officials-of-2012/.

66. See Roger M. Witten et al., Prescriptions for Compliance with the Foreign Corrupt Practices Act: Identifying Bribery Risks and Implementing Anti-Bribery Controls in Pharmaceutical and Life Sciences Companies, 64 Bus. LAw. 691, 697 (2009). For example, Alcatel Lucent SA was charged for paying a Malaysian telecomm entity, Telekom Malaysia Berhad, which had a $43 \%$ public ownership stake and was considered a government entity for the purposes of the FCPA. Joseph W. Yockey, Solicitation, Extortion, and the FCPA, 87 Notre DAME L. Rev. 781, 822, 822 n.195-97 (2011). 
sectors is often far from clear, the agencies" "foreign official" interpretation has proven highly consequential. ${ }^{67}$

Another policy question concerns the relevant benefit that a corporation must receive in exchange for its payment to a foreign official. The statutory language requires that a bribe be intended to "obtain and retain business," which, under some readings, might be limited to payments used to rig the bidding in auctions for government procurement contracts. ${ }^{68}$ In contrast, a number of settlements are premised on a broader interpretation that reaches regulatory preferences of all kinds, such as decisions regarding tax treatments or licensing approvals. ${ }^{69}$ Despite the settlements' liberal interpretation of what it means to "obtain and retain business," that definition is potentially cabined by a related statutory safe harbor, known as the "facilitating payments" exception. The facilitating payments exception provides that, regardless of the nature of the benefit received, there is no liability in cases where the foreign official was obligated by law to provide the benefit but withheld it in order to extort further corporate payments. ${ }^{70}$ In practice, however, that exception has been whittled away to the point of being regarded as "illusory." 71 Thus, in insurance law parlance, regulatory settlements have expanded the FCPA's coverage provisions and narrowed its exclusion provisions: the standard which results is that liability can be triggered when a corporation receives a wide range of favorable decisions from a foreign official, whether or not the benefits involved were legally owed to the company in the first place.

A few more significant examples can be noted briefly. The FCPA includes a knowledge requirement for violations of the book-and-records and internal controls provisions: after multiple settlements that turn on those violations, however, the scienter element has seemingly been

67. A rare interpretation of the foreign official provision was recently provided by the Eleventh Circuit, but that opinion applied a vague "totality of the circumstances" style test, and appears to have only sown further confusion in this area. United States v. Esquenazi, 752 F.3d 912, 920-24 (11th Cir. 2014), superseded by statute, Fraud Enforcement and Regulatory Act of 2009, Pub. L. No. 111-21, 123 Stat. 1617 (codified at 18 U.S.C. § 1956(c)(9)), as recognized in United States v. Gross, 661 F. App'x 1007, 1022-23 (11th Cir. 2016); see generally Amy Lynn Soto, United States v. Esquenazi: Injecting Clarity or Confusion into the Foreign Corrupt Practices Act, 47 U. MiAMI. INTER-AM. L. REV. 383 (2016).

68. See Mike Koehler, The Foreign Corrupt Practices ACt In A New Era 90-98 (Edward Elgar Publ'g Ltd., 2014).

69. Id.

70. Omnibus Trade and Competitiveness Act of 1988, Pub. L. No. 100-418, §§ 5001-03, 102 Stat. 1107, 1415-25 (amending 15 U.S.C. §§ 78m(b), 78dd-1, 78dd-2, 78ff(1988)).

71. See generally Richard Grime \& Sara Zdeb, The Illusory Facilitating Payments Exception: Risks Posed by Ongoing FCPA Enforcement Actions and the U.K. Bribery Act, in THE FOREIGN CORRUPT PRACTICES ACT 2011 377, 382-89 (Richard Grime et al. ed., 2011). 
refashioned into a strict liability standard. ${ }^{72}$ The agencies' jurisdiction over foreign corporations, which is limited by a condition that bribes must be associated with actions that share a territorial nexus with the United States, has been extended by settlements that find such a connection based on little or no actual contact, and therefore grant the statute an essentially global reach. ${ }^{73}$ Settlements have also taken statutory language which declares that "anything of value" may constitute a bribe quite literally, and have signaled that the definition can be satisfied not only by cash payments, but also with a wide variety of non-monetary goods (t-shirts; executive training programs) and indirect benefits (charitable donations; internships for relatives). ${ }^{74}$

The track record of FCPA enforcement against individuals reinforces the intuition that the statutory interpretations and theories of liability implicit in the corporate settlements are neither conservative nor obvious. Corporate liability logically entails individual culpability in most instances, yet the DOJ and SEC have largely hesitated to bring parallel actions against individuals. ${ }^{75}$ When they do-presumably in the subset of cases which are strongest on the merits - they frequently fail. ${ }^{76}$ Moreover, the government's setbacks in court tend to involve the interpretation of

72. 15 U.S.C. $\S 78 \mathrm{~m}(\mathrm{~b})(5)$. See, e.g., Nature's Sunshine Prods., Inc., Litigation Release No. 21161, 2009 WL 2356796 (July 31, 2009); Avery Dennison Corp., Litigation Release No. 21156, 2009 WL 2243830 (July 28, 2009); Dow Chemical Co., Litigation Release No. 20000, 2007 WL 460874 (Feb. 13, 2007); see Mike Koehler, The Façade of FCPA Enforcement, 41 GEO. J. INT'L L. 907, 97681 (2010).

73. As established by the 1998 Amendments, foreign corporations may be subject to FCPA liability if they either issue securities on U.S exchanges, or if they have contact with U.S. territory "in furtherance of" conduct prohibited by the statute. 15 U.S.C. $\S \S 78 \mathrm{~m}(\mathrm{~b})(2)(\mathrm{A}), 78 \mathrm{dd}-1$ (a), 78dd-2(a), 78dd-3; see Daniel Patrick Ashe, The Lengthening Anti-Bribery Lasso of the United States: The Recent Extraterritorial Application of the U.S. Foreign Corrupt Practices Act, 73 FORDHAM L. REV. 2897, 2902-03, 2917-18 (2005).

74. JP Morgan Chase \& Co., Exchange Act Release No. 79335, 2016 WL 6804113 (Nov. 17, 2016) (involving internships for relatives); UTStarcom, Inc., Litigation Release No. 21357, 2009 WL 5171952 (Dec. 31, 2009) (concerning payment of training programs); Titan Corp., Litigation Release No. 19107, 2005 WL 474238 (Mar. 1, 2005) (involving campaign t-shirts); Schering-Plough Corp., Litigation Release No. 18740, 2004 WL 1268036 (June 9, 2004) (concerning donations to a Polish hospital).

75. During the 17-year "quiet period" of FCPA enforcement, 20 of 24 DOJ actions against companies also included charges against individuals; in the boom era, less than a quarter, 20 of 84, have done the same. See Koehler, Foreign Corrupt Practices Act Enforcement, supra note 54, at 53141. The SEC also does not pursue individual charges, which have accompanied only $17 \%$ of the agency's corporate actions since 2008. See A Focus on SEC Individual Actions, FCPA PROFESSOR BLOG (Jan. 27, 2015), http://fcpaprofessor.com/a-focus-on-sec-fcpa-individual-actions-3/.

76. See Paul Barrett, Plea Deals Are Easy, Juries Are Hard, BLOOMBERG BusinessweEK (July 23, 2015, 3:49 PM), https://www.bloomberg.com/news/articles/2015-07-23/u-s-prosecutors-keeplosing-trials-in-overseas-corruption-cases. 
key provisions that were reviewed above. ${ }^{77}$ It is revealing that in several cases rejecting the government's legal theories, the court has specifically admonished prosecutors for citing prior enforcement actions as legal authority. ${ }^{78}$ This suggests that the agencies themselves have internalized the regulation by settlement concept.

In 2012, the DOJ and SEC jointly released a guidance document, titled "A Resource Guide to the U.S. Foreign Corrupt Practices Act" (the FCPA Guidance), ${ }^{79}$ partially in response to growing demands that the agencies produce a more explicit articulation of their theory of the law. But the document was widely panned for adding little new clarity to the agencies' understanding of what the FCPA means. ${ }^{80}$ Rather than laying out policy positions or enforcement philosophies in unambiguous terms that would provide direction to regulated parties, the FCPA Guidance mostly consists of hypothetical examples that are supported by citations to prior settlements. ${ }^{81}$ An ironic result was that it functioned to reaffirm the

77. See, e.g., SEC v. Sharef, 924 F. Supp. 2d 539, $548-49$ (S.D.N.Y. 2013) (acquitting, dismissing with prejudice, and rejecting the government's jurisdictional theory); SEC v. Jackson, 908 F. Supp. 2d 834, 855 (S.D. Tex. 2012) (finding that the SEC had failed to meet the preponderance of evidence burden of proof in a "facilitating' payments" case against an individual, where it had previously agreed to $\$ 260$ million in corporate settlements on the same legal theory); Order Dismissing with Prejudice, United States v. Goncalves, No. 09 -cr-00335 (D.D.C. Feb. 23, 2012) (dismissing case and rejecting government's "foreign official" theory); Final Dismissal, United States v. O'Shea, No. 09-cr-00629 (S.D. Tex. Feb. 9, 2012) (rejecting the government's "facilitating payments" theory); Mem. Op. and Order at 9, SEC v. Mattson, No. H-01-3106 (S.D. Tex. Sept. 9, 2002) (rejecting government's interpretation of "obtain or retain business."); Motion for Acquittal, United States v. Pou, No. 89-00802 (S.D. Fla. April 17, 1990) (arguing for the court to reject the government's interpretation of "obtain or retain business"); Judgment for Acquittal, United States v. Duran, No. 8900802 (S.D. Fla. Apr. 17, 1990) (granting Duran's Motion for Acquittal);

78. United States v. Bodmer, 342 F. Supp. 2d 176, 187 n.10 (S.D.N.Y. 2004) ("The Government's charging decision, standing alone, does not establish the applicability of the statute."); United States v. Giffen, 326 F. Supp. 2d 497, 505 (S.D.N.Y. 2004) (stating that prior record of settlements "is not the kind or quality of precedent this Court need consider").

79. FCPA Guidance, supra note 51.

80. See Muma, supra note 60, at 1344 ("Th[e] [FCPA Guidance] does not expand greatly on what practitioners in the field already know, however, and it does not substantially clarify the underlying uncertainty in the FCPA's definitions."); Wayne M. Carlin, White Collar and Regulatory Enforcement: Emerging Trends, HARV. L. SCH. F. ON CORP. GOVERNANCE \& Fin. REG. (Jan. 30, 2013) https://corpgov.law.harvard.edu/2013/01/30/white-collar-and-regulatory-enforcementemerging-trends/ ("[T]he FCPA Resource Guide broke little new legal or policy ground"); Joe Palazzolo \& Christopher M. Matthews, U.S. Attempts to Clarify Antibribery Law, WALl ST. J. (Nov. 14, 2012, 6:59 PM), https://www.wsj.com/articles/SB100014241278873247351045781188501814 34228 (quoting a former chief of the DOJ's Fraud Section calling the FCPA Guidance "more of a scrapbook of past DOJ and SEC successes than a guide book for companies who care about playing by the rules").

81. What discernible positions it did stake out had the curious intermediate character: more tentative than settlements yet bolder than court cases that rejected those theories. See Mike Koehler, Grading the Foreign Corrupt Practices Act Guidance, 7 White Collar CRIME ReP. (BNA) 961, 961, 963-64 (Dec. 14, 2012) [hereinafter Koehler, Grading the FCPA Guidance] ("[P]ast FCPA 
precedential value of FCPA settlements rather than displace them with a more traditional policymaking vehicle. Thus, most of the major policy decisions relating to federal anti-corruption law-questions of scienter, jurisdiction, what counts as a bribe, who counts as a bribe recipient, what counts as a bribed benefit-have been determined by de facto rules promulgated through regulatory settlements.

\section{The Securitization Settlements}

A major cause of the recent financial crisis was an interconnection between large banks and the housing market that was forged by a multistep process of financial engineering known as "securitization." 82 In the first step of that process, mortgage originators would pool groups of home loans and sell them into trusts held by third-party banks. The banks would then issue certificates from those trusts, which offered investors a fixed cash flow derived from payments on the underlying mortgage loans (Mortgaged-Backed Securities or MBS). In a further iteration, the MBS themselves were securitized, by being pooled and used to back securities known as Collateralized Debt Obligations (CDOs). The earliest use of securitization goes back decades, but markets in MBS and other financial instruments that securitization churns out only grew to be a substantial component of the banking sector following a boom decade that began in the mid-1990s. ${ }^{83}$

When the housing market deteriorated over the 2006-07 period, homeowners' rates of default on their mortgages spiked, which in turn led to a collapse in the value of MBS, CDOs, and related financial instruments that were indirectly linked to home loans. ${ }^{84}$ Because large financial institutions had adopted fragile funding models that were vulnerable to any reversals in structured finance markets, a spectacular series of failures followed over the course of 2008, culminating in the bankruptcies of Lehman Brothers and $\mathrm{AIG}^{85}$ Once the financial system eventually stabilized, regulators shifted from the emergency crisis management tactics that characterized "regulation by deal," and initiated a concerted

enforcement actions, in whole or in part, have seemingly run counter to the statements [in the Guidance; . . . [meanwhile,] what the enforcement agencies say in the Guidance has been rejected, in whole or in part, by courts").

82. See generally Steven L. Schwarcz, What is Securitization? And for What Purpose?, 85 S. CAL. L. REV. 1283 (2012).

83. See Viral V. Acharya et Al., Regulating Wall StreEt: The DodD-Frank ACT AND THE NEW ARChITECTURE OF GLOBAL FinANCE 469-71 (2010).

84. See id. at $470-71$.

85. See Davidoff \& Zaring, supra note 6, at 491-504. 
series of enforcement actions that targeted the banks' securitization practices leading up to the crisis.

A first round of settlements was spearheaded by the SEC. The opening volley was an investigation of Goldman Sachs - announced while Dodd-Frank was still being hotly debated in Congress - which resulted in a $\$ 550$ million settlement that was made public on July 15, 2010, a week before the statute was passed. ${ }^{86}$ The SEC's underlying claim was that Goldman had misled a pair of European banks that invested in its synthetic CDO transaction, known as ABACUS 2007-AC1, by failing to disclose that a hedge fund manager named John Paulson played a role in selecting the collateral backing the deal while simultaneously betting against it. ${ }^{87}$

The ABACUS investigation was only the first of a campaign of enforcement actions brought by the SEC against the big banks. In each case, the agency alleged that banks had made misrepresentations to investors in connection with the issuance of CDOs or similar structuredfinance securities. By mid-2014, every one of those actions were resolved out-of-court with settlement agreements that imposed eight- or nine-figure penalties. ${ }^{88}$ In total, the SEC collected over $\$ 3.76$ billion in fines ${ }^{89}$

A second round of settlements took place after the Obama administration established the "RMBS Working Group" in 2012, which is an executive branch task force with the specific mission of redressing wrongdoing associated with the financial crisis. ${ }^{90}$ While nominally led by the DOJ, the RMBS Working Group is a multi-agency body that coordinates enforcement efforts among the full alphabet soup of federal

86. Goldman, Sachs \& Co., Litigation Release No. 21592, 2010 WL 2799362 (July 15, 2010) (announcing the settlement); Goldman, Sachs \& Co., Litigation Release No. 21489, 2010 WL 1514183 (Apr. 16, 2010) (announcing that the SEC charged Goldman, Sachs \& Co.); The SEC's Impeccable Timing, WALL ST. J. (Apr. 20, 2010, 12:01 AM), https://www.wsj.com/articles/ SB10001424052748704671904575194172722146804.

87. Amended Complaint, SEC v. Goldman Sachs \& Co., 790 F. Supp. 2d 147 (S.D.N.Y. 2010) (No. 10-CV-3229), 2010 WL 5863739.

88. The SEC reached settlements with Wachovia (\$11 million; April 5, 2011), J.P. Morgan (\$154 million; June 21, 2011), Citigroup (\$285 million; October 19, 2011), J.P. Morgan (\$297 million; November 16, 2012), Credit Suisse (\$120 million; November 16, 2012), UBS (\$50 million; August 6, 2013), Royal Bank of Scotland (\$150 million; November 7, 2013), Merrill Lynch (\$132 million; December 12, 2013), and Morgan Stanley (\$275 million; July 24, 2014). SEC Enforcement Actions: Addressing Misconduct that Led To or Arose from the Financial Crisis, SEC. \& EXCH. COMM'N (Oct. 7, 2016), https://www.sec.gov/spotlight/enf-actions-fc.shtml.

89. Id.

90. Press Release, U.S. Dep't of Justice, Attorney General Holder Speaks at the Announcement of the Financial Fraud Enforcement Task Force's New Residential Mortgage-Backed Securities Working Group (Jan. 27, 2012), https://www.justice.gov/opa/speech/attorney-general-holder-speaksannouncementof-financial-fraud-enforcement-task-force-s. The RMBS Working Group is embedded in a broader organization, the Financial Fraud Enforcement Task Force, which was formed by the Obama administration in 2009. Exec. Order No. 13,519, 74 Fed. Reg. 60,123 (Nov. 17, 2009). 
financial regulators, along with several state attorneys general. ${ }^{91}$ While the SEC followed a transaction-specific approach, with each settlement covering allegations in connection with a particular securitization deal, the RMBS Working Group undertook broader investigations that focused on financial institutions as a whole. Starting in 2014, those efforts quickly yielded a string of blockbuster, multi-billion dollar settlements with the big banks, through which the RMBS Working Group has imposed over $\$ 57$ billion in aggregate penalties. ${ }^{92}$

In addition to the unprecedented dollar amounts involved, one of the most salient features of the Securitization Settlements was their comprehensive reach. The SEC could have aimed its investigative resources at the most egregious instances of wrongdoing, which, presumably, would be associated with transactions at some institutions more than others. Instead, it pursued a conspicuous strategy of "one fine

91. Federal agencies associated with the RMBS Working Group included: the SEC, Federal Reserve Board, FDIC, Consumer Financial Protection Bureau (CFPB), Department of Housing and Urban Development (HUD), Federal Housing Finance Agency (FHFA), and National Credit Union Administration (NCUA). Press Release, U.S. Dep't of Justice, supra note 90.

92. J.P. Morgan Chase ( $\$ 13$ billion; February 10, 2014); Citigroup ( $\$ 7$ billion; July 13, 2014); Bank of America ( $\$ 16.6$ billion; August 21, 2014); Morgan Stanley (\$2.6 billion; February 11, 2016); Wells Fargo (\$1.2 billion; April 8, 2016); Goldman Sachs (\$5 billion; April 11, 2016); Deutsche Bank (\$7.2 billion; December 23, 2016); and Credit Suisse ( $\$ 5.3$ billion; December 23, 2016). Press Release, U.S. Dep't of Justice, Justice Department, Federal and State Partners Secure Record \$13 Billion Global Settlement with JPMorgan for Misleading Investors About Securities Containing Toxic Mortgages (Nov. 19, 2013), https://www.justice.gov/opa/pr/justice-department-federal-and-statepartners-secure-record-13-billion-global-settlement; Press Release, U.S. Dep't of Justice, Justice Department, Federal and State Partners Secure Record \$7 Billion Global Settlement with Citigroup for Misleading Investors About Securities Containing Toxic Mortgages (July 14, 2014), https://www.justice.gov/opa/pr/justice-department-federal-and-state-partners-secure-record-7-

billion-global-settlement; Press Release, U.S. Dep’t of Justice, Bank of America to Pay \$16.65 Billion in Historic Justice Department Settlement for Financial Fraud Leading up to and During the Financial Crisis (Aug. 21, 2014), https://www.justice.gov/opa/pr/bank-america-pay-1665-billion-historicjustice-department-settlement-financial-fraud-leading; Press Release, U.S. Dep't of Justice, Morgan Stanley Agrees to Pay \$2.6 Billion Penalty in Connection with Its Sale of Residential Mortgage Backed Securities (Feb. 11, 2016), https://www.justice.gov/opa/pr/morgan-stanley-agrees-pay-26billion-penalty-connection-its-sale-residential-mortgage-backed; Press Release, U.S. Dep't of Justice, Wells Fargo Agrees to Pay \$1.2 Billion for Improper Mortgage Lending Practices (Apr. 8, 2016), https://www.justice.gov/opa/pr/wells-fargo-bank-agrees-pay-12-billion-improper-mortgage-lendingpractices; Press Release, U.S. Dep't of Justice, Goldman Sachs Agrees to Pay More than \$5 Billion in Connection with Its Sale of Residential Mortgage Backed Securities (Apr. 11, 2016), https://www.justice.gov/opa/pr/goldman-sachs-agrees-pay-more-5-billion-connection-its-saleresidential-mortgage-backed; Press Release, U.S. Dep’t of Justice, Deutsche Bank Agrees to Pay $\$ 7.2$ Billion for Misleading Investors in Its Sale of Residential Mortgage-Backed Securities (Jan. 17, 2017), https://www.justice.gov/opa/pr/deutsche-bank-agrees-pay-72-billion-misleading-investors-its-saleresidential-mortgage-backed; Press Release, U.S. Dep’t of Justice, Credit Suisse Agrees to Pay \$5.28 Billion in Connection with Its Sale of Residential Mortgage-Backed Securities (Jan. 18, 2017), https://www.justice.gov/opa/pr/credit-suisse-agrees-pay-528-billion-connection-its-sale-residentialmortgage-backed. 
per bank." 93 Similarly, the RMBS Working Group has adopted what could be considered a "market share" theory of corporate liability. The institutions singled out for settlement were simply the largest banks in the country; among those settling banks, the bigger the volume of their securitization business, the higher the fine. ${ }^{94}$ The same philosophy is reflected in the individual settlement agreements themselves, which follow a standard format. First there is a Statement of Facts, which recites from an unrelated grab-bag of internal bank communications, all of which betray an embarrassing disregard for due diligence practices and other forms of quality control. ${ }^{95}$ That random assortment of allegations is then accompanied by a blanket assertion of liability for the full population of MBS transactions (usually numbering in the hundreds) that the bank participated in over a multi-year period during the height of the U.S. housing bubble era. ${ }^{96}$ By targeting the banks' entire course of business and leaving no institution unscathed, the Securitization Settlements sent a signal that the standard practices of the industry as a whole had violated the regulatory rules of the road.

Identifying the exact legal basis that underpinned those rules, however, is far from straightforward. The rapid rise of securitization was not accompanied by the development of a related regulatory framework, and structured finance markets therefore operated within a relative legal vacuum as part of the so-called "shadow banking sector." 97 A consequence was that regulators improvised an "eclectic" approach to

93. See Zaring, supra note 28, at 1412-13 ("The resulting list of FIRREA settlementsapproximately one per large bank, in an interesting parallel to the approximately one securities fraud settlement with the Securities Exchange Commission ('SEC') per bank-looks like real money.").

94. See Ryan Bubb \& Prasad Krishnamurthy, Regulating Against Bubbles: How Mortgage Regulation Can Keep Main Street and Wall Street Safe - From Themselves, 163 U. PA. L. REV. 1539, 1582 tbl. 1 (2015) (describing the securitization activity of big banks).

95. See, e.g., Annex 1 - Statement of Facts to April 2016 Goldman Sachs Settlement Agreement, DEP'T OF JUSTICE, https://www.justice.gov/opa/file/839901/download (last visited Oct. 16, 2017).

96. See, e.g., Annex 3 to April 2016 Goldman Sachs Settlement Agreement, DEP'T OF JustiCE, https://www.justice.gov/opa/file/839911/download (last visited Oct. 16, 2017) (listing covered transactions); see also Floyd Norris, Citigroup's Settlement, Pro and Con, N.Y. Times (July 17, 2014), https://www.nytimes.com/2014/07/18/business/what-the-citigroup-settlement-gets-right-and-

wrong.html?mcubz=0 ("But the [DOJ] stops short of identifying which securitizations were affected and never bothers to say whether the securitizations with problems performed worse than others. There is no indication that officials checked to see whether the loans identified as substandard were more likely to default than those the consultants deemed to be proper. There seems to have been no effort to quantify just how much Citigroup's improper behavior cost investors.").

97. See Erik F. Gerding, Bank Regulation and Securitization: How the Law Improved Transmission Lines Between Real Estate and Banking Crises, 50 GA. L. REv. 89, 98, 106-07 (2015); Zoltan Pozsar et al., Shadow Banking 15 (Fed. Reserve Bank of N.Y. Staff Reports, No. 458, 2010), https://papers.ssrn.com/sol3/papers.cfm?abstract_id $=1640545$. 
enforcement that featured a "diversified portfolio" of legal theories. ${ }^{98}$ As in the FCPA context, however, the agencies' outside-the-box thinking was only minimally embraced by the courts, and " $[t]$ here has not been a single conviction of a bailed-out bank, or a single senior executive who ran one." 99 Thus, the general picture that arises from the Securitization Settlements is an industry-wide imposition of fines that is not conditioned on a clear connection between particular acts of wrongdoing nor a widely recognized, preexisting legal basis for liability.

The SEC settlements, for example, were premised on the banks having committed federal securities fraud, but that same theory did not gain traction in cases that were litigated against individuals. An important early test was a DOJ case that brought criminal securities fraud charges against two Bear Stearns hedge fund managers. When both individuals were acquitted on all counts, the DOJ was forced to reassess its financial crisis litigation strategy more generally, and subsequently dropped most of its other pending investigations. ${ }^{100}$ Meeting civil standards of proof was not noticeably easier. ${ }^{101}$ An SEC litigation against Citigroup trader Brian Stoker led to a jury verdict that rejected the government's theory of liability, even though the allegations in that case concerned the very same CDO transaction that was the basis for a $\$ 285$ million settlement with the bank itself. ${ }^{102}$ The SEC's most prominent success in a securitization case,

98. Zaring, supra note 28, at 1411-12 ("These civil suits have relied on a mix of statutes-that is, they did not all turn on violations of the securities laws or on other fraud claims. With various agencies in action, and various bases for litigation, the best way to characterize the government's civil enforcement strategy is to think of it as a diversified portfolio.... [T] he eclectic approach taken by the government [regarding theories of liability] is likely to be the definitive one for the crisis.").

99. Id. at 1438; see also Todd Haugh, The Most Senior Wall Street Official: Evaluating the State of Financial Crisis Prosecutions, 9 VA. L. \& BUS. REV. 153, 167-187 (2015) (discussing the paucity of convictions against senior bankers); $c f$. United States ex rel. O'Donnell v. Countrywide Home Loans, Inc., 822 F.3d 650, 653 (2nd Cir. 2016) (reversing a jury verdict of civil fraud against mortgage originator Countrywide, on grounds of insufficient evidence).

100. See Jean Eaglesham, Financial Crimes Bedevil Prosecutors, Wall St. J. (Dec. 6, 2011), https://www.wsj.com/articles/SB10001424052970204083204577080792356961440 (reporting on DOJ dropping cases that were being prepared against AIG executive Joseph Cassano and Countrywide CEO Angelo Mozilo); Zachery Kouwe \& Dan Slater, Two Bear Stearns Fund Leaders Are Acquitted, N.Y. Times (Nov. 10, 2009), http://www.nytimes.com/2009/11/11/business/11bear.html?mcubz=0 (reporting on the acquittal of Bear Sterns Managers Ralph Cioffi and Matthew Tannin).

101. Zaring, supra note 28, at 1410-11.

102. Peter Lattman, S.E.C. Gets Encouragement from Jury That Ruled Against It, N.Y. TIMES (Aug. 3, 2012, 5:23 PM), https://dealbook.nytimes.com/2012/08/03/s-e-c-gets-encouragement-fromjury-that-ruled-against-it/?mcubz=1. A nearly identical scenario played out again when the SEC dropped its case against another individual, Edward Steffelin, which was based on allegations that resulted in a \$296 million settlement with J.P. Morgan for the same underlying CDO transaction. See Peter J. Henning, Mixed Results for S.E.C. in Financial Crisis Cases, N.Y. TIMES (Nov. 19, 2012, 3:36 PM), https://dealbook.nytimes.com/2012/11/19/mixed-results-for-s-e-c-in-financial-crisis-cases/?mc $\mathrm{ubz}=0$. 
a jury verdict against Goldman Sachs' employee Fabrice Tourre for civil securities fraud, is best understood as an idiosyncratic exception that proves the rule. ${ }^{103}$

Rather than invoke the federal securities laws, the RMBS Working Group settlements relied on a creative patchwork of statutes that had previously been of limited applicability to banking regulation. ${ }^{104}$ One of these was FIRREA, a law passed in response to the 1980s savings-andloan crisis, which imposes civil liability for acts of fraud committed against banks with federally-insured deposits. ${ }^{105}$ FIRREA had never before been used against bank entities, only against individuals. ${ }^{106}$ But the statute gained legs in connection with the government's novel "selfaffecting" theory, which turned on the idea that the defrauded bank and settling bank were one and the same. ${ }^{107}$ Another legal component of the RMBS Working Group settlements was the False Claims Act (FCA), a Civil War era qui tam statute that prohibits false statements made to agencies in connection with government contracts or the receipt of other public benefits. ${ }^{108}$ The FCA was foreign to financial regulation prior to 2008, but was applied on the theory that the banks had made false statements to government housing agencies (Fannie Mae, Freddie Mac, or HUD) in the process of certifying mortgages that were used in securitizations. ${ }^{109}$ A third legal authority that was invoked were state "blue

103. Tourre was a mid-level financial engineer rather than a decision-making executive, and was rendered particularly unsympathetic by emails in which he declared himself the "Fabulous Fab" and claimed credit for ushering in a financial apocalypse. See Aaron Smith \& James O'Toole, 'Fabulous Fab' Held Liable in Goldman Fraud Case, CNN Money (Aug. 1, 2013, 6:21 PM), http://money.cnn.com/2013/08/01/news/companies/tourre-goldman-verdict/index.html.

104. Nick Timiraos et al., U.S. Steps up Loan Scrutiny, WALL ST. J. (May 21, 2011, 12:01 AM), https://www.wsj.com/articles/SB10001424052748704083904576335582428039612 ("The Justice Department has instructed federal prosecutors to be creative in adapting decades-old laws to take action against Wall Street ....”).

105. Financial Institutions Reform, Recovery, and Enforcement Act of 1989 § 951, 12 U.S.C. § 1833a (2012) (providing for civil penalties); see Nan S. Ellis, Steven B. Dow \& David Safavian, Use of FIRREA to Impose Liability in the Wake of the Global Financial Crisis: A New Weapon in the Arsenal to Prevent Financial Fraud, 18 U. PA. J. Bus. L. 119, 130-33 (2015) (describing FIRREA's civil penalties).

106. Ellis et al., supra note 105, at 135, 135 n.75 ("Although FIRREA was enacted in 1989, it was virtually ignored as a vehicle to address financial fraud until the [financial crisis]... Previously, FIRREA had been used primarily against officers and directors of failed financial institutions.").

107. Id. at 139 .

108. 31 U.S.C. $\S \S 3729-3733$ (2012) (appearing as amended by Fraud Enforcement and Recovery Act of 2009, Pub. L. No. 111-21, 123 Stat. 1617); see U.S. DeP'T OF Justice, The FaLSE Claims ACT: A PRIMER 1-3 (2011), https://www.justice.gov/sites/default/files/ civil/legacy/2011/04/22/C-FRAUDS_FCA_Primer.pdf.

109. See F. Joseph Warin et al., Financial Institutions in the Crosshairs: The False Claims Act and FIRREA, GIBSON DUNN 25-32 (Oct. 2, 2013), http://www.gibsondunn.com/ publications/Documents/FinancialInstitutionsInCrosshairs-webcast-October2013.pdf. 
sky laws," which predate the Great Depression and had been largely dormant since. ${ }^{110}$ During the rise of structured finance markets, it is unlikely that any of these statutes or associated theories of liability were perceived as the governing legal backdrop for banks' securitization practices.

Taken at face value, the Securitization Settlements carry a startling implication: every major bank, in connection with every securitization deal, had simultaneously defrauded investors (under federal and state securities laws), the government (the False Claims Act), and themselves (FIRREA). But that vision of omnipresent fraud lacks plausibility, not only due to its inherent oddness, but also in light of the paltry success of related claims that reached adjudication on the merits. A more convincing interpretation is that the underlying conduct, as economically destructive as it proved to be, did not involve fraud in the conventional sense of intentional deception. ${ }^{111}$ Rather, the banks which bought and sold securitized assets from one another had formed a circular firing squad of collectively misguided risk-taking. ${ }^{112}$ When a generalized drift toward lax risk management met an historic drop in housing prices, the worst case scenario materialized. ${ }^{113}$ Because that chain of events was nonetheless subject to a comprehensive sweep of regulatory settlements that imposed record-setting fines, a novel regulatory "rule" emerges. The implicit legal standard is that banks can be held liable (on a nearly unlimited dollar basis)

110. The most prominent blue sky law is New York's Martin Act. N.Y. GEN. BUS. LAW $§ 353$ (McKinney 2012) (permitting suits against anyone who "has engaged in, is engaged or is about to engage in any of the practices or transactions heretofore referred to as and declared to be fraudulent practices"); see Roberta S. Karmel, Reconciling Federal and State Interests in Securities Regulation in the United States and Europe, 28 BROOK. J. INT'L L. 495, 544 n.272 (2003) (reporting that the Martin Act was rarely used "except to prosecute local scams" for most of its history).

111. See Hilary J. Allen, The Pathologies of Banking Business as Usual, 17 U. PA. J. BUS. L. 861, 876 (2015); Samuel W. Buell, What Is Securities Fraud?, 61 DuKE L.J. 511, 554 (2011); Daniel C. Richman, Corporate Headhunting, 8 HARV. L. \& PoL'Y REV. 265, 267-68 (2014); cf. Mitu Gulati et al., Fraud by Hindsight, 98 Nw. U. L. REV. 773 (2004) (describing the tendency for securities fraud cases to turn on retrospective judgments where the attribution of intentional wrongdoing is influenced by bad economic or business outcomes).

112. Cf. Arnold Kling, The Financial Crisis: Moral Failure or Cognitive Failure?, 33 HARV. J.L. \& PUB. POL'Y 507, 508-09 (2010) (arguing the financial crisis is perhaps better explained not by the "narrative of moral failure," but by the "narrative of cognitive failure," "in which executives and regulators overestimated the risk-mitigating effects of quantitative modeling and financial engineering"); Geoffrey P. Miller \& Gerald Rosenfeld, Intellectual Hazard: How Conceptual Biases in Complex Organizations Contributed to the Crisis of 2008, 33 HARV. J.L. \& PUB. POL'Y 807, 808 (2010) ("Intellectual hazard . . . is the tendency of behavioral biases to interfere with accurate thought and analysis within complex organizations ... [and] was a cause of the Crisis of 2008.").

113. See Kling, supra note 112, at 508-509 (discussing the "cognitive failures" that led to the financial crisis of 2008); Miller \& Rosenfeld, supra note 112, at 821-825 (discussing the "intellectual hazards" demonstrated by banks during the financial crisis). 
for engaging in negligent or grossly negligent business practices when participating in securitization markets.

A complicating factor is that the Securitization Settlements occupy the same regulatory space as the Dodd-Frank Act, which is conventionally understood to represent an overhaul of the law of securitization. ${ }^{114}$ However, Dodd-Frank does not preempt the regulatory standard laid down by the Securitization Settlements, because its rules are merely redundant with preexisting industry practice and also narrower than the theories of liability that animated the settlements. For example, Section 941 of DoddFrank provides "risk retention" rules, which require banks to hold a portion of the securities (roughly five percent) that are issued from their securitization. ${ }^{115}$ But risk retention was already standard prior to the financial crisis. ${ }^{116}$ In fact, all of the RMBS Working Group settlements involved banks that had retained greater than twenty percent of the risk from their securitization deals, which is more than four times the new "requirement" set out by Dodd-Frank. ${ }^{117}$

Another relevant Dodd-Frank provision is Section 942(b), which sets out new disclosure rules that require banks to disclose information regarding the financial assets backing each class of securities that are issued as part of a securitization. ${ }^{118}$ As with risk retention, the sort of disclosures contemplated by Section 942(b) were already the industry norm. Most securitizations were accompanied by a battery of offering documents- "term sheets," "offering circulars," "free writing prospectuses," "prospectus supplements"-which contained hundreds of

114. See Steven L. Schwarcz, Securitization and Post-Crisis Financial Regulation, 101 CoRNELL L. REV. ONLINE 115, 117 (2016), http://cornelllawreview.org/files/2016/10/SchwarczOnline Essayfinal.pdf (stating that the "U.S. regulatory responses to securitization are primarily embodied in the Dodd-Frank Act").

115. 15 U.S.C. § 78o-11 (2012). The rationale for Dodd-Frank's risk retention rule is that, by forcing banks to retain a portion of the credit risk that is passed along to investors, they will be incentivized to do greater due diligence on the collateral backing the deal. See Bubb \& Krishnamurthy, supra note 94 , at $1567-68$.

116. See Acharya, supra note 83, at 469 ("Financial institutions actually held on to large chunks of (mostly senior) tranches of their securitized assets."); Bubb \& Krishnamurthy, supra note 94, at 1547 ("The market-determined level of risk retention by securitizers during the recent boom was in fact too high, not too low. The same Wall Street banks that led the league tables for the creation of MBS also bore much of the brunt of the losses when the underlying loans failed."); Schwarcz, supra note 114, at 126 ("In my experience, the market itself has always mandated risk-retention. Prior to the financial crisis, for example, originators and sponsors of securitizations usually retained risk on the financial assets, typically mortgage loans, included in those transactions.") (footnote omitted).

117. Bubb \& Krishnamurthy, supra note 94, at 1581, 1582 tbl. 1.

118. Dodd-Frank Wall Street Reform and Consumer Protection Act, Pub. L. No. 111-203, § 942(b), 124 Stat. 1376, 1897 (2010) (codified at 15 U.S.C. $\S \$ 77 \mathrm{~g}$ (c) (2012)); see also $\S 945,124$ Stat. at 1898 (codified at $\S 77 \mathrm{~g}(\mathrm{~d})(2012)$ ) (regarding disclosure of due diligence). 
pages of statistics that described the securities being sold. ${ }^{119}$ The irrelevance of Section 942(b) is best illustrated by Goldman Sachs' $\$ 550$ million ABACUS settlement. There, the SEC focused on a failure to disclose "soft" circumstantial information regarding the role of certain parties involved in the deal, and did not allege any misrepresentations or omissions regarding the financial characteristics of the securities at issue. ${ }^{120}$ Thus, conduct that is prohibited under the new Dodd-Frank rules never actually took place during the financial crisis, while conduct that would be in perfect compliance with those rules resulted in across-theboard regulatory settlements that imposed billions of dollars in penalties. The real overhaul of the regulatory framework for securitization was installed through the Securitization Settlements, rather than by DoddFrank.

\section{The Benchmark Settlements}

An important part of the banking system involves the use of financial benchmarks, which are aggregation devices that reflect market-wide prices and are often incorporated into contractual terms. ${ }^{121}$ The most famous of these, Libor (the London Inter-Bank Offered Rate), is an index that is calculated based on banks' estimates of their borrowing costs and then factored into the price of interest rate swaps. ${ }^{122}$ Because Libor represents the lowest interest rate that the market will bear at a given time, it is also widely relied upon as a baseline to price consumer debt-such as mortgages, credit cards, and student loans - and has therefore been called "the "world's most important number." ${ }^{123}$ Benchmarks are also critical in

119. See Schwarcz, supra note 114, at 125 ("Prior to the financial crisis, the risks associated with complex securitization transactions and their underlying financial assets, including subprime mortgage loans, were fully disclosed .... The problem is that disclosure alone can be ineffective for highly complex securitization products. For example, the task of deciphering a prospectus, hundreds of pages long and full of detailed technical and legal phraseology, is usually burdensome even for the most sophisticated institutional managers ... ."); see also Steven L. Schwarcz, Disclosure's Failure in the Subprime Mortgage Crisis, 2008 UTAH L. REV. 1109, 1110, 1110 n.6 (2008) ("Most, if not all, of the risks giving rise to the collapse of the market for securities backed by subprime mortgages were disclosed, yet the disclosure was insufficient, in part because complexity made the risks very difficult to understand. The prospectus itself in a typical offering of these securities is, in my experience, hundreds of pages long.").

120. See Stephen M. Davidoff et al., The SEC v. Goldman Sachs: Reputation, Trust, and Fiduciary Duties in Investment Banking, 37 J. CORP. L. 529, 540-42 (2012).

121. See Andrew Verstein, Benchmark Manipulation, 56 B.C. L. REV. 215, 217 (2015).

122. Melissa Anne Conrad-Alam, All Together Now: International Regulatory Response to the LIBOR Rate Setting Conspiracy, 42 GA. J. INT'L \& COMP. L. 491, 494-95 (2014).

123. See id. at 492. ("Today, around the world, financial institutions, investment markets, mortgage companies, and private investment funds use LIBOR as the reference point for determining interest rates."). 
foreign exchange markets, where the $\mathrm{W} / \mathrm{M} /$ Reuters index is a popular tool for pricing currency swaps and other financial contracts that are used in the five trillion dollar market associated with hedging exchange rate fluctuations. ${ }^{124}$ The regulation of benchmarks was fundamentally changed by two sweeping waves of settlements concerning allegations that various banks had been manipulating, or "rigging," the calculation of Libor (the Libor Settlements) and the W/M/Reuters index (the ForEx Settlements) (together, the Benchmark Settlements).

The path to the Libor Settlements began on May 29, 2008, when a Wall Street Journal article raised suspicions that the banks were manipulating the benchmark by reporting their borrowing costs in a strategic manner. ${ }^{125}$ That eventually lead to an investigation of Barclays by the CFTC, which ended with Barclays entering into three separate settlements on June 27, 2012 - one with the CFTC (\$200 million), another with the DOJ (\$160 million), and a third with the UK Financial Services Authority (\$92.8 million). ${ }^{126}$ The Barclays settlement involved three underlying allegations. First, that Barclays swaps traders in New York had been communicating with the banks' money market desk in London, and requesting that the London office alter its Libor submissions upwards or downwards, in order to push the benchmark in a direction that would favor Barclays in its trades with clients. ${ }^{127}$ Second, that separate requests to coordinate Libor submissions had been made between Barclays traders and traders at other banks, with the same aim of front-running clients. ${ }^{128}$ And third, that high-level managers at Barclays had under-reported Libor submissions to regulators around the $2007-09$ period - a time when every large financial institution was being scrutinized as potentially on the brink of collapse - in an attempt to make the bank's financial position appear stronger. ${ }^{129}$ The Barclays settlement sparked a broader investigation,

124. See Fin. Stability Bd., Foreign Exchange Benchmarks: Consultative Document 5-6 (2014), http://www.fsb.org/wp-content/uploads/r_140715.pdf.

125. Carrick Mollenkamp \& Mark Whitehouse, Study Casts Doubt on Key Rate, Wall ST. J. (May 29, 2008, 12:01 AM), https://www.wsj.com/news/articles/SB121200703762027135. Libor is "fixed" daily, based on voluntary submissions by a panel of approximately sixteen large banks, which provide estimates of the rate at which they anticipate being able borrow over variously time intervals (e.g. three months) and in different currencies. It is calculated as the average of the reported rates after high-and-low outliers have been dropped. See Conrad-Alam, supra note 122, at 494-96, 501.

126. Ben Protess \& Mark Scott, Barclays Settles Regulators' Claims over Manipulation of Key Rates, N.Y. TIMES (June 27, 2012), https://dealbook.nytimes.com/2012/06/27/barclays-said-to-settleregulatory-claims-over-benchmark-manipulation/.

127. In re Barclays PLC, 2012 CFTC Lexis 39, at *5 (2012) (order instituting proceedings, making findings, and imposing remedial sanctions).

128. Id.

129. Id. at $* 9$. 
which quickly produced a series of agreements among the CFTC, DOJ, FDIC, UK authorities and other banks that had a role in setting in Libor. ${ }^{130}$ Enforcement of the Libor manipulation scandal resulted in settlements totaling $\$ 9$ billion. ${ }^{131}$

An eerily similar chain of events was set in motion on June 12, 2013, when an international group of regulators opened wide-ranging investigations into the possible manipulation of the W/M/Reuters benchmark in foreign exchange markets. ${ }^{132}$ While ForEx benchmarks are aggregated based on actual trades, rather than submissions that estimate borrowing costs, those probes uncovered evidence that traders coordinated within and across firms - including in chat rooms with unhelpful names like "the cartel" - to strategically concentrate transactions in the trading window that was used to calculate $\mathrm{W} / \mathrm{M} /$ Reuters, with the aim of biasing the benchmark in directions that were advantageous to the banks' trading positions. ${ }^{133}$ A surge of regulatory settlements followed, which managed to exceed the Libor Settlements in scale. On November 11, 2014, the CFTC announced nine-figure settlements with five banks and, on that same day, the OCC finalized three separate settlements of equal magnitude. ${ }^{134}$ On May 20, 2015, the DOJ settled criminal charges through agreements with five banks, one of which was joined by the New York Department of Financial Services (NY DFS), while the Federal Reserve Board announced civil settlements with the same group. ${ }^{135}$ Total penalties associated with the ForEx settlements equaled \$10.3 billion.

130. UBS (\$1.5 billion; Dec. 19, 2012); Royal Bank of Scotland (\$612 million; Feb. 6, 2013); ICAP ( $\$ 87$ million; Sept. 25, 2013); Rabobank ( $\$ 1$ billion; Oct. 29, 2013); Deutsche Bank $(\$ 2.5$ billion; Apr. 23, 2015). Tracking the Libor Scandal, N.Y. TIMES (last updated Mar. 23, 2016), https://www.nytimes.com/interactive/2015/04/23/business/dealbook/db-libortimeline.html?mcubz=1\#/\#time370_10900.

131. David Reid, This Scandal-hit Interest Rate Used to Set Mortgages Is To End in 2021, CNBC (July 27, 2017), https://www.cnbc.com/2017/07/27/scandalous-libor-rate-to-end-in-2021.html.

132. See Phillipa Leighton-Jones \& Stephen Grocer, How the FX Probe Unfolded, WaLl ST. J.: MONEYBEAT (Nov. 12, 2014), https://blogs.wsj.com/moneybeat/2014/11/12/how-the-fx-probeunfolded/.

133. Id.

134. The CFTC settled with: Citibank ( $\$ 310$ million); HSBC ( $\$ 275$ million); JP Morgan ( $\$ 310$ million); RBS (\$290 million); and UBS (\$290 million). The OCC settled with: Bank of America (\$250 million); JP Morgan (\$350 million); and Citibank (\$350 million). See Matt Levine, Bank FX Fine Scorecard (Follow Along at Home!), BloomBerg VIEW (May 20, 2015), https://www.bloomberg.com/view/articles/2015-05-20/bank-fine-scorecard-follow-along-at-home-.

135. The DOJ settled with: Citigroup ( $\$ 925$ million); JP Morgan ( $\$ 550$ million); Barclays ( $\$ 710$ million; joined by the NY DFS for an additional \$485 million); RBS (\$395 million); and UBS (\$203 million). The Federal Reserve Board settled with: Citigroup (\$342 million); JP Morgan (\$342 million); Barclays (\$342 million); RBS (\$274 million); Bank of America (\$205 million); and UBS (\$342 million). Id. 
The core features of the Benchmark Settlements closely paralleled aspects of the Securitization Settlements that allowed regulators to use those agreements to engage in de facto regulatory rulemaking. Namely: (1) massive penalties that were applied on a comprehensive, industrywide scale; (2) the imposition of those penalties through enforcement actions that nearly all concluded with corporate settlements; and (3) the assertion of creative theories of liability that did not closely track any preexisting regulatory framework.

The Benchmark Settlements signaled that the reliability of the Libor and ForEx indices was undermined by a widespread set of standard practices, rather than an outlier group of malfeasant firms. Libor is calculated by a panel of sixteen banks, and almost every member of the panel became a party to regulatory settlements. ${ }^{136}$ Moreover, although the Barclays settlement publicized a collection of outrageous quotes from bankers who were brazenly trading rigged submissions in exchange for bottles of champagne and the like, it eventually became clear that such behavior was not particularly shocking to industry veterans, who assumed that the Libor numbers had been massaged at the margins for decades. ${ }^{137}$ Likewise, ForEx markets are relatively concentrated, with about ten banks transacting in the trading window that is used to calculate W/M/Reuters and similar benchmarks. ${ }^{138}$ All or nearly all of those banks entered into nine-figure settlements with regulators. And, in the ForEx context, the underlying conduct may also have been roughly in line with the expectations of market participants: funneling trades into the relevant window in which the benchmark is "fixed" is to a certain extent a required practice, albeit one that need not be performed in an aggressively opportunistic manner. ${ }^{139}$ Thus, as with the Securitization Settlements, liability was attached to the normal course of dealing of an entire industry.

Once again, the dominant procedural vehicle for imposing liability was corporate settlement. All $\$ 19.3$ billion in penalties were extracted in connection with out-of-court settlements, which were negotiated without

136. Edward V. Murphy, Cong. Research Serv., R42608, LIBOR: Frequently Asked QUESTIONS 1 (2012), https://fas.org/sgp/crs/misc/R42608.pdf (noting that the Libor panel was composed of 18 banks in 2012); see also BBA LIBOR Panels 2006, BRITISH BANKER's ASs'N (June. 23, 2006), http://www.bankfacts.org.uk/bba/jsp/polopoly.jsp?d=145\&a=7327 [https://web.archive. org/web/20061003072145/http://www.bankfacts.org.uk/bba/jsp/polopoly.jsp?d=145\&a=7327] (noting that the Libor panel was composed of 16 U.S. banks in 2006).

137. See, e.g., Douglas Keenan, My Thwarted Attempt to Tell of LIBOR Shenanigans, FIN. TIMES (July 26, 2016), https://www.ft.com/content/dc5f49c2-d67b-11e1-ba60-00144feabdc0; The LIBOR Scandal: Rotten Heart of Finance, THE ECONOMIST (July 7, 2012), http://www.economist.com/node/21558281.

138. Verstein, supra note 121, at 237-38.

139. See Levine, supra note 134. 
a single defendants' legal brief being filed in either administrative or federal court. While certain of the DOJ's ForEx settlements were nominally styled as "guilty pleas," rather than deferred prosecution agreements, that label was misleading. The admissions of guilt in those documents were immediately followed by waivers that negated any of the collateral consequences that are usually associated with guilty pleasnamely, ineligibility for government contracting and collateral estoppel in follow-on civil suits-and were therefore treated by markets as indistinguishable from pretrial diversion agreements that contained no such admissions. ${ }^{140}$ And as with the financial crisis litigations, related actions against individuals were sparse, directed exclusively at low-level traders, and were rejected on the merits more often than not. ${ }^{141}$

Most importantly, the Benchmark Settlements amounted to an implicit exercise in progressive regulatory rulemaking, rather than a crackdown on clear-cut violations of a well-established, preexisting legal prohibition. As it turned out, there was essentially no formal "benchmark regulation" in place at the time the manipulation allegations surfaced. ${ }^{142}$ The Libor system was managed by the British Bankers Association (BBA), a nowinfamous gentleman's agreement governed by the very same panel of banks that made the submissions which were aggregated into the benchmark rate. ${ }^{143}$ The ForEx benchmark was similarly supervised by a light-touch association of industry members, known as the London Foreign Exchange Joint Standing Committee. ${ }^{144}$ The minimalist state of benchmark regulation is best illustrated by the fact that the BBA was the first to be informed of the allegations underlying the Barclays settlement, undertook a perfunctory investigation in 2008, and concluded within a matter of months that no major changes needed to be made to the system. ${ }^{145}$

As a result of this regulatory void, the Benchmark Settlements invoked a bewildering mix of statutes and legal theories, none of which were

140. See Hugh Son \& Elizabeth Dexheimer, Once-Unthinkable Criminal Pleas by U.S. Banks Get Investor 'Meh', BLOOMBERG (May 20, 2015), https://www.bloomberg.com/news/articles/201505-20/once-unthinkable-criminal-pleas-by-u-s-banks-get-investor-meh-.

141. See Lindsay Fortado, Jury Acquits Five of Six Brokers in Libor Trial, Fin. TIMES, (Jan. 27, 2016), https://www.ft.com/content/f5689ae2-c509-11e5-808f-8231cd71622e; see also Caroline Binham, Justice Department Weighs Charges Against London ForEx Traders, Fin. TiMES (Apr. 22, 2016), https://www.ft.com/content/63caaa34-07db-11e6-a623-b84d06a39ec2.

142. Gina-Gail S. Fletcher, Benchmark Regulation, 201 IowA L. REV. 1929, 1930-34 (2017).

143. See Conrad-Alam, supra note 122, at 498-500 (reviewing oversight of Libor by the BBA).

144. Leighton-Jones \& Grocer, supra note 132. See also Conrad-Alam, supra note 122, at 498.

145. See Stephen M. Bainbridge, Reforming LIBOR: Wheatley Versus the Alternatives, 9 N.Y.U. J.L. \& Bus. 789, 798-99 (2013). 
squarely applicable to the conduct at issue. ${ }^{146}$ For example, the OCC, FDIC, and Federal Reserve Board settlements all rely on a catchall provision from the Federal Deposit Insurance Act (FDIA), which prohibits practices that are inconsistent with maintaining the overall "safety and soundness" of a bank. ${ }^{147}$ Yet those settlements do not explain how the banks' finances were rendered more fragile by the (profitable) manipulation of the Libor or ForEx benchmarks. ${ }^{148}$ Instead, they imply that the relevant unsafe practices involved the banks' failure to detect their employees' attempts to manipulate those financial benchmarks. As a result, the findings of liability in those settlements are entirely derivative of an underlying theory of wrongdoing that is never articulated and presumed to have been established elsewhere.

The antitrust violations asserted in the DOJ's settlements are also awkward in the benchmark context. For instance, the underlying allegations were that the banks had colluded to underestimate Libor in many cases, and thereby lowered prices for end-users of debt contracts as often as not. ${ }^{149}$ More importantly, antitrust claims by definition only apply to behavior that is coordinated among firms, and cannot reach attempts at benchmark manipulation - no matter how egregious - that take place within a single firm.

The common denominator across the Benchmark Settlements were agreements involving the CFTC, which were premised on a dual violation of both the fraud and manipulation prohibitions contained in the Commodity Exchange Act (CEA). ${ }^{150}$ It has been widely recognized by commentators, however, that each theory runs into fundamental conceptual and evidentiary problems. The CFTC's commodities manipulation claims are weak because, among other reasons, it is difficult

146. See Milson C. Yu, Note, Libor Integrity and Holistic Domestic Enforcement, 98 CORNELL L. REV. 1271, 1276 (2013) ("The conclusion, then, is quite clear: contemporary statutory and regulatory regimes are inadequate to effectively capture reference rates and holistically enforce against their manipulation.").

147. Federal Deposit Insurance Act of 1950, Pub. L. No. 81-797, § 8(b)(1), 64 Stat. 873 (codified as amended at 12 U.S.C. $\S \S 1818(b)(1), 1818(1)$ (2012)). See, e.g., JPMorgan Chase Bank, N.A., Case No. AA-EC-14-100 (Nov. 11, 2014), https://www.occ.gov/static/enforcement-actions/ea2014172.pdf (consent order for civil money penalty).

148. JPMorgan Chase Bank, N.A., supra note 147, at 5 ๆ 14.

149. See Sharon E. Foster, LIBOR Manipulation and Antitrust Allegations, 11 DEPAUL BUS. \& COMM. L.J. 291, 318-19 (2013) ("If LIBOR has been manipulated down, at least since 2008, the theory goes that these debtors would benefit by the lower interest rates.").

150. See supra notes 127, 134, and accompanying text; see also Commodity Exchange Act, Pub.

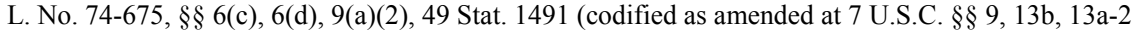
(2012)). 
to construe financial benchmarks as "commodities."151 The fraud claims are undermined by the fact that manipulation of the ForEx benchmark involved strategically timed trades, not deceptive statements. ${ }^{152}$ Nor do Dodd-Frank's amendments to the CEA's fraud provisions-which move the relevant legal standard closer to the $10 \mathrm{~b}-5$ rule that prevails in securities law-completely close those gaps. ${ }^{153}$

As should be clear, the precise admixture of legal theories that underpinned the Benchmark Settlements is somewhat beside the point. By extracting penalties from every bank that had a significant role in Libor and ForEx swap markets, using whatever statute happened to be on hand, administrative agencies leveraged the settlement of enforcement actions to establish a new regulatory norm. Roughly stated, the controlling rule is that liability for manipulation of a financial index will be forthcoming whenever data or trades are submitted in a strategic manner that undermines the overall integrity of the final benchmark rate. ${ }^{154}$

In addition to that background standard, the Benchmark Settlements also incorporated terms that established new rules governing banks' dayto-day administration of the financial benchmarks. This was accomplished through the CFTC-Barclays agreement, which set forth a roughly twenty-page template of detailed procedural reforms that was mechanically grafted onto subsequent Libor settlements. ${ }^{155}$ The

151. See Verstein, supra note 121, at 252 ("[The Commodities Exchange Act and other] antimanipulation probation statutes have not been operationalized in a manner that adequately discourages benchmark manipulation.”).

152. It is also hard to establish the fraud element of reliance when the rigging at issue was an open secret among industry actors, who worked together to move benchmark prices. See Yu, supra note 146, at 1277, 1291 (making these points); Fletcher, supra note 142, at 1936-37, 1936 n.34 (same); Verstein, supra note 121, at 255-58 (same).

153. Dodd-Frank amended Sections 4 and 6(c)(1) of the CEA, and the CFTC promulgated a pair of associated rules, known as Reg.180.1 and Reg. 180.2. But see Verstein, supra note 121, at 254-55 (Dodd-Frank amendments, even if retrospectively applied, would not have covered all of the conduct at issue in the Benchmark Settlements).

154. Cf. Verstein, supra note 121, at 261-62.

155. For example, the Barclays Settlement sets out specific factors that may be used in calculating Libor, how they are to be weighed relative to one another, and so on. In re Barclays PLC, 2012 CFTC Lexis 39, at *17-18 (2012); see Hester Peirce, Regulating Through the Backdoor at the Commodities Futures Trading Commission 59-60 (Nov. 2014) (unpublished manuscript), https://www.mercatus.org/system/files/Peirce-Back-Door-CFTC.pdf. Although such terms bear a superficial resemblance to the internal governance provisions that are routinely included in DOJ pretrial diversion agreements, they are in fact much more substantive in nature because the underlying content of benchmark regulation is procedural, and consists of the protocols that are used to aggregate those indices. Compare In re Barclays PLC, supra, with Letter from Denis J. McInerney, Chief of Fraud Section of U.S. Dep't of Justice Criminal Div., to Gary R. Spratling and David P. Burns (Dec. 18, 2012), https://www.sec.gov/Archives/edgar/data/1114446/000119312513106100/d497201dex43. htm (setting out the standard NPA compliance terms). See also Andrew Verstein \& Gabriel V. Rauterberg, Assessing Transnational Private Regulation of the OTC Derivatives Market: ISDA, the 
prescriptive quality of the Benchmark Settlements is most apparent in light of parallel reform efforts in the UK, where the leading policy document (known as the Wheatley Report) explicitly endorses the procedures outlined in the CFTC-Barclays settlement and adopts them as the defining guidelines for Libor submissions by UK banks going forward. ${ }^{156}$ Thus, in the case of the Benchmark Settlements, regulatory settlements have been used both to fashion a new regulatory prohibition, which covers a broad range of attempts at rate "manipulation," and to lay down a standardized framework for how the calculation of certain indices is managed.

\section{Summary}

The three case studies presented above include some of the clearest and most impactful episodes of regulation by settlement. But they nonetheless represent an illustrative rather than exhaustive set of examples. Within the past decade, many other areas of banking regulation have been fundamentally altered by agencies engaging in settlement-only enforcement booms. Four additional cases are worth noting in order to highlight the pervasive reach of regulation by settlement but will be surveyed in passing for purposes of space.

One further example involves enforcement actions against banks that originated and serviced residential mortgages (the Mortgage Servicing Settlements). From 2010 to 2012, the OCC, Federal Reserve Board, and Department of Housing and Urban Development (HUD), entered into a sweeping series of settlements with banks relating to their foreclosure practices, which imposed a total of $\$ 25$ billion in penalties. ${ }^{157}$ Like the Securitization Settlements, the Mortgage Servicing Settlements took a comprehensive "market share" theory of liability in order to reform the industry as a whole: the five largest settlements were with banks that had the five highest volumes of foreclosures. ${ }^{158}$ Another example is a

BBA, and the Future of Financial Reform, 54 VA. J. INT'L L. 9, 35 (2013) (characterizing the invasive internal controls stipulated-to in the Barclay's Libor settlement as "regulation by settlement").

156. See The Wheatley Review, The Wheatley Review of Libor: Final Report, 29 \ 4.9

(2012) ("These [Libor] submission guidelines are closely modelled on the undertakings proposed by the Commodity Futures Trading Commission (CFTC) in their settlement with Barclays Bank Plc.").

157. See generally Sally Scott \& Jerry Anthony, National Mortgage Settlement 2-3 (Oct. 1, 2012) (unpublished manuscript), https://ir.uiowa.edu/ppc_social_policy/6/.

158. See id. at 3. Like the CFTC's agreements in the Benchmark Settlements, the OCC and Federal Reserve Board agreements contained vast remedial terms, which went beyond enhanced compliance procedures and dictated a new set of substantive industry standards governing foreclosures on mortgage loans. See OFFICE OF COMPTROLLER OF CURRENCY, FORECLOSURE-RELATED CONSENT ORDERS STATUS REPORT: OBSERVATIONS, PAYMENTS, AND FORECLOSURE PREVENTION ASSISTANCE (Apr. 2014). 
collection of settlements that focused on the internal procedures that banks use to detect money laundering activities that take place through client accounts (the Anti-Money Laundering Settlements). ${ }^{159}$ A third case concerns settlements pursued by the DOJ and the Treasury's Office of Foreign Assets Control (OFAC), which invoke executive orders that place economic sanctions on certain foreign governments, and allege that banks failed to deter or detect financial transactions with those countries (the Foreign Sanctions Settlements). ${ }^{160}$ A final example is the Swiss Bank Settlements, in which the DOJ entered into seventy-eight NPAs with internationally-active financial institutions within a two-year span over the course of 2015 and 2016, all arising from claims that subsidiary banks located in Switzerland were used as tax havens that illegally sheltered the assets of U.S. citizens. ${ }^{161}$

This section has walked through multiple series of settlements in a highly granular way, but that level of detail is necessary to move beyond truisms, such as the point that enforcement decisions can influence policy, or that out-of-court settlement agreements have become more common. The analysis thereby shows that recent enforcement episodes share a number of subtle features which, taken collectively, represent a regime change in financial regulation. Time and again, regulatory settlements have been used on a systematic scale to indirectly promulgate novel legal standards and thereby reshape how the banking system operates along important dimensions. In these areas, the legal center of gravity now consists of a body of settlement agreements, while traditional textual authorities (statutes, judicial opinions, regulatory rules, agency policy statements, the rulings of administrative courts, and so on) are limited to the periphery. One consequence is that, contrary to conventional wisdom, post-crisis financial regulation is not wholly the domain of the Dodd-Frank

159. The list of agencies that took part in the Anti-Money Laundering Settlements includes the DOJ, the OCC, the Federal Reserve Board, and the "FinCEN" unit of the Treasury Department. The underlying legal basis for corporate liability turned primarily on alleged violations of the Bank Secrecy Act. See Sharon Brown-Hruska, Developments in Bank Secrecy Act and Anti-Money Laundering Enforcement and Litigation, NERA ECON. CONSUlTING 5 (June 2016), http://www.nera.com/content/dam/nera/publications/2016/PUB_Developments_BSA_AML_Lit06.16.pdf; Lanier Saperstein et al., The Failure of Anti-Money Laundering Regulation: Where is the Cost-Benefit Analysis?, 91 Notre Dame L. Rev. OnLine 1, 10 n.44 (2015); Olivia A. Radin, A Rising Tide of AML Reg Actions-And What We Can Learn, LAw360 (Mar. 31, 2015, 10:43 AM), https://www.law360.com/articles/637334/a-rising-tide-of-aml-reg-actions-and-what-we-can-learn.

160. See Victoria Anglin, Note, Why Smart Sanctions Need a Smarter Enforcement Mechanism: Evaluating Recent Settlements Imposed on Sanction-Skirting Banks, 104 GEO. L. J. 693, 704-08 (2016).

161. See Garrett, supra note 41, at 38; Gibson Dunn Client Alert, supra note 37, at 4; Swiss Bank Program, U.S. DEP'T OF JUST. (Feb. 6, 2017), https://www.justice.gov/tax/swiss-bank-program. 
Act. Instead, regulation by settlement has emerged as a parallel form of regulation that stands alongside that statutory framework.

\section{REgulation By SETtLEMENT \& THE AdMINISTRATIVE StATE}

This Section explores the significance of regulation by settlement within the broader context of administrative law and argues that its unique procedural features represent a novel form of agency policymaking. Part A outlines the legal balancing of discretion and constraint that characterizes the standard model of regulation in the administrative state. Part B demonstrates how regulation by settlement departs from those baseline principles, by comparing the recent use of regulatory settlements against more conventional modes of agency action. In the process, the discussion that follows aims to shed light on the current divide between scholarship on financial regulation and administrative law, and takes some steps to bridge that gap.

\section{A. Background Principles of Regulatory Policymaking}

Administrative law scholarship circulates around certain points of consensus that can be understood to collectively reflect a standard model of how the modern regulatory state operates. An initial premise is that administrative agencies are the predominant source of national public policy. Although Congress is vested with legislative authority under Article I of the Constitution, it has nearly unlimited leeway to make a de facto delegation of that authority to the executive branch, so long as the statute that does so contains an "intelligible principle" that provides some minimal guidance as to what transfer has taken place. ${ }^{162}$ In practice such wholesale delegations are commonplace, and legislation frequently sets out only the barest outlines of political consensus. ${ }^{163}$ Administrative agencies, therefore, go much further than filling in the gaps left by ambiguous statutory language, ${ }^{164}$ and instead do the real work of policymaking that determines the substance of how the federal government actually governs. ${ }^{165}$

162. See Whitman v. Am. Trucking Ass'n, 531 U.S. 457, 472 (2011) (setting out the "intelligible principle" requirement of the nondelegation doctrine).

163. See Eric A. Posner \& Adrian Vermeule, Interring the Nondelegation Doctrine, 69 U. CHI. L. REV. 1721, 1729 (2002); Mark Seidenfeld, Bending the Rules: Flexible Regulation and Constraints on Agency Discretion, 51 ADMIN. L. REV. 429, 438-39 (1999).

164. For the inevitability of broad administrative policymaking, see Bressman, supra note 1, at 1758-67; Stewart, supra note 1, at 1669-70.

165. See William N. Eskridge, JR. \& John Ferejohn, A Republic of Statutes: The NeW 
Concentrating policymaking discretion in the executive branch is considered a defensible institutional division of labor rather than an act of Congressional abdication. ${ }^{166}$ The justification is that agencies' superior decision-making flexibility and technocratic expertise relative to Congress make them more adept at intervening in the complex problems that arise in an advanced capitalist society. ${ }^{167}$ A further point is that, in order to meaningfully exploit those advantages, agencies must necessarily exercise an overlapping combination of legislative, executive, and judicial functions in a way that may (superficially, at least) appear to be in tension with traditional separation of powers commitments. ${ }^{168}$ Although the pairing of expertise and discretion is desirable in the first instance, it nonetheless raises anxieties over agencies' accountability, legitimacy, and reasoned decision-making. ${ }^{169}$ In order to assuage those concerns, agency discretion is hemmed-in by a byzantine patchwork of constraintsimposed variously by Congress, the federal judiciary, and from within the executive branch hierarchy itself. ${ }^{170}$

Policymaking by regulatory agencies is most often associated with a specific legal mechanism, notice-and-comment rulemaking, which is the closest administrative analogue to Congressional legislation. ${ }^{171}$ But there is no legal basis for prioritizing that particular procedure. A foundational doctrine of administrative law, known as the Chenery principle, holds that

AMERICAN CONSTITUTION 10 (2010) ("[I]n the modern administrative state, commissions and bureaus promulgate most legally binding rules."); Gary Lawson, The Rise and Rise of the Administrative State, 107 HARV. L. REV. 1231, 1241 (1994).

166. Administrative bodies are often subdivided into "executive" agencies, housed within the traditional executive departments, such as the Treasury, and "independent" agencies, such as the SEC and CFTC, with the latter having a different appointment and removal structure. See Lisa Schultz Bressman \& Robert B. Thompson, The Future of Agency Independence, 63 VAND. L. REV. 599, 610 (2010); Adam J. Levitin, The Politics of Financial Regulation and the Regulation of Financial Politics: A Review Essay, 127 HARV. L. REV. 1991, 2042-49 (2014) (examining relevance of distinction in context of financial regulatory agencies).

167. See JAMEs LANDis, The AdMINISTRATIVE Process 23-24 (1938) (regarding expertise); William E. Scheuerman, Liberal Democracy and the Social ACCEleration of Time 124 (2004) (regarding flexibility).

168. See generally M. Elizabeth Magill, Beyond Powers and Branches in Separation of Powers Law, 150 U. PA. L. ReV. 603, 607-08 (2001). See also AdriAn VERMEule, LAW's AbNEGATION: FROM LAW'S EMPIRE TO THE ADMINISTRATIVE STATE 56-74 (2016) [hereinafter VERMUELE, LAW'S ABNEGATION]; LANDIS, supra note 167, at 46.

169. See generally Lisa Schultz Bressman, Beyond Accountability: Arbitrariness and Legitimacy in the Administrative State, 78 N.Y.U. L. REV. 461 (2003).

170. Because the executive power that Article II purports to lay out is more or less missing, the history of administrative law is largely the story of how the varying sources and strengths of those constraints have been improvised over time. See generally JERRY L. MASHAW, CREATING THE Administrative CONSTITUTION: THE LOST OnE HundRED YEARS OF AMERICAN Administrative LAW (2012).

171. See Stewart, supra note 10 , at 444 . 
agencies have discretion to rely on whichever policymaking vehicle they prefer. ${ }^{172}$ That doctrine opens up a broad menu of procedural fora, which is jointly defined by the "organic" statute that Congress uses to delegate its authority to an agency, along with the Administrative Procedure Act (APA), which applies across statutes. The full range of agency actions that follow can be reduced to three categories: rulemaking (with formal and informal variants); adjudication (also with formal and informal variants); and enforcement (through claims brought either in administrative or federal court).

At first glance, the Chenery choice-of-forum principle threatens the equilibrium of discretion and constraint that underpins the standard model of agency decision-making. That balance is nonetheless maintained, however, in light of two tradeoffs that tend to apply across the different forms of regulatory policymaking. The first is a "formality-review" tradeoff. When agencies elect to use relatively "formal" decision-making procedures to set policy - in other words, methods that impose a greater burden on the agency because they are more deliberative, participatory, or transparent to outside observers - those decisions receive less judicial scrutiny. This tradeoff is explicitly introduced by judicial doctrines that determine which standards of review (for example, Chevron or Skidmore deference) apply to which agency actions. ${ }^{173}$ It also arises through a more subtle process, in which courts apply seemingly identical legal tests - such as the arbitrary-and-capricious standard-more or less stringently depending on the procedural context in which an agency has acted. ${ }^{174}$ The overall effect is that agency avoidance of ex ante (procedural) constraints is offset by greater ex post (judicial) constraints. ${ }^{175}$

The second principle that applies across forms of administrative policymaking is a "substance-discretion" tradeoff, in which agency decisions that have a greater influence over substantive policy receive more scrutiny from other governmental actors. Agencies can influence the substance of policy by either adopting statutory interpretations that are relatively bold compared to plausible textual alternatives, or by

172. SEC v. Chenery Corp., 332 U.S. 194 (1947); cf. NLRB v. Bell Aerospace Co., 416 U.S. 267, 289-90 (1974) (affirming Chenery II).

173. See Thomas W. Merrill \& Kristin E. Hickman, Chevron's Domain, 89 Geo. L.J. 833, 852 (2001).

174. Magill, supra note 16, at 1439-41; David Zaring, Reasonable Agencies, 96 VA. L. REV. 135, $164-65$ (2010).

175. Cass Sunstein has labelled this tradeoff the "pay me now or pay me later" principle. Sunstein, supra note 16, at 225-26; see also VERMEULE, LAW'S ABNEGATION, supra note 168, at 81; Mark Seidenfeld, Substituting Substantive for Procedural Review of Guidance Documents, 90 TEX. L. REV. 331, 360-61 (2011). 
intervening in issue areas that are of major significance to public policy. ${ }^{176}$ When they do so, more intensive review will follow through one of two mechanisms. First, there is the so-called "strategic substitution effect," which means that when agencies undertake ambitious policy decisions they will preemptively adopt more formal procedures in order to survive subsequent levels of review. ${ }^{177}$ Second, a number of supplemental constraints-which may include judicial doctrines, executive branch protocols, or congressionally-mandated procedures - are triggered when agencies decide to aggressively push the direction of policy. In short, the substance-discretion tradeoff means that when agencies make more vigorous use of policy delegations, that latitude is counterbalanced by additional ex post or ex ante constraints.

To be sure, the one constant in administrative law is endless doctrinal caveats and a general over-complexity. The two dynamics sketched above, therefore, represent systemic patterns rather than iron laws. Yet they are sufficiently widespread that scholars have been motivated to search out genres of agency "unorthodoxy," where the normal balance of legal constraint does not apply. ${ }^{178}$ The two most prominent cases, mentioned in the Introduction, are the regulation of emergencies and executive inaction. ${ }^{179}$ A good example of the latter is the Obama administration's choice to refrain from applying portions of the federal drug laws that relate to marijuana. ${ }^{180}$ That decision evades the formalityreview tradeoff because it was promulgated through a handful of informal policy statements and DOJ memoranda, yet managed to sidestep judicial scrutiny under cover of the Heckler v. Chaney doctrine - which holds that the executive's decision to not enforce the law cannot (in most cases) be reviewed by the courts. ${ }^{181}$ At the same time, the Obama administration's decision also eludes the Substance-Discretion Tradeoff, since it fundamentally altered the substance of federal anti-drug policy without being subject to the checks that would have accompanied analogous alternatives, such as a massive revision to the federal sentencing guidelines governing the sale or possession of marijuana. ${ }^{182}$

176. Cf. Magill, supra note 16, at 1414 ("The greater the magnitude of the agency action, the more intense the judicial examination is likely to be.").

177. See Stephenson, supra note 17; Magill, supra note 16, at 1446-47.

178. See supra notes 3-4.

179. See supra notes 3-5.

180. See generally Bradley E. Markano, Note, Enabling State Deregulation of Marijuana Through Executive Branch Nonenforcement, 90 N.Y.U. L. REV. 289 (2015).

181. Heckler v. Chaney, 470 U.S. 821, 832 (1985).

182. Markano, supra note 180 , at 302-04. 
With regulation by settlement, a new form of agency unorthodoxy has emerged. Although this Article focuses on that development within the financial regulation context, the rise of regulatory settlements is significant for administrative law as a whole. One reason is that - despite the habit of scholarship on the subject to draw its source material from agencies that are responsible for environmental, health, or safety regulation-there is a growing appreciation that financial regulation is the quintessential administrative law field. ${ }^{183}$ In addition, a recent influx of landmark agency-firm settlements in other areas, such as the automotive and pharmaceutical industries, suggests that regulation by settlement may be migrating to other portions of the administrative state as well. ${ }^{184}$

\section{B. Regulation by Settlement versus Standard Forms of Agency Policymaking}

The best way to understand the uniquely unconstrained quality of regulation by settlement is through a close comparison between that practice and the more conventional modes of regulatory policymaking: administrative rulemaking, adjudication, and enforcement. The discussion below undertakes that examination by touring a broad and somewhat technical range of administrative law doctrines. A clear pattern emerges in the process. While the dual tradeoffs of regulatory policymaking (formality-review and substance-discretion) consistently apply across the full menu of agency actions, they prove to be entirely inapplicable to regulation by settlement. As a result, regulation by settlement slips free of the balance of constraint and discretion that is otherwise maintained for both formal and informal agency policymaking forms.

\section{Rulemaking}

The APA technically designates a particular "formal" rulemaking procedure, but it is almost never used. ${ }^{185}$ Instead, the most formal

\footnotetext{
183. See supra notes 20-21.

184. Cf. William Yeatman, Executive Lawmaking in EPA-Justice Department-Volkswagen Settlement, Notice \& COMMENT (Oct. 1, 2016), http://yalejreg.com/nc/executive-lawmaking-in-epajustice-department-volkswagen-settlement-by-william-yeatman/ (discussing DOJ's and EPA's settlements with Volkswagen for violation of the Clean Air Act and false advertising); Press Release, U.S. Dep't of Justice Office of Pub. Affairs, Justice Department Recovers \$3 Billion in False Claims Act Cases in Fiscal Year 2011 (Dec. 19, 2011), https://www.justice.gov/opa/pr/justice-departmentrecovers-3-billion-false-claims-act-cases-fiscal-year-2011 (detailing recent FCA settlements with pharmaceutical companies).

185. 5 U.S.C. $§ 553(\mathrm{c})$ (2012) (providing conditions that require formal rulemaking); see United States v. Fla. E. Coast Ry. Co., 410 U.S. 224, 237-38 (1973) (interpreting the APA triggers narrowly).
} 
rulemaking that actually takes place is performed pursuant to the noticeand-comment (n\&c) procedures laid out in APA Section 553. That provision requires agencies to undertake three steps when promulgating a regulatory rule: (1) publish a notice of proposed rulemaking in the Federal Register; (2) allow interested parties the opportunity to comment on the proposal; and (3) provide a response that considers the comments that have been made. ${ }^{186}$ In addition to the APA's requirements, n\&c rulemaking is further constrained by a review process that takes place within the executive branch-overseen by the President's Office of Management Budget (OMB) and its subsidiary department, the Office of Information \& Regulatory Affairs (OIRA) - which requires that an agency submit a detailed cost-benefit analysis of its proposed rule for OIRA approval before that rule can be finalized. ${ }^{187}$ Regulations that are finalized through the n\&c process are considered "legislative rules," meaning that they carry the "force of law" in the same way that a Congressional statute does. ${ }^{188}$

Agencies also have an inherent authority to engage in rulemaking outside of the n\&c process, by issuing what Section 553 of the APA refers to as "interpretive rules" or "statements of policy." 189 Agencies frequently take advantage of this exception from the more formal $\mathrm{n} \& \mathrm{c}$ procedures to issue a wide array of documents, which are collectively known by shorthand as "guidance." 190 The regulatory standards set forth in agency guidance usually constitute "nonlegislative rules," which lack the freestanding legal authority of n\&c rules. ${ }^{191}$ The "nonlegislative" label captures the presumption that guidance documents concern comparatively

186. 5 U.S.C. $\S 553(b)-(c)$.

187. The OMB-OIRA review process was established by a series of executive orders that date back to the Reagan administration. See generally Cass R. Sunstein, The Office of Information and Regulatory Affairs: Myths and Realities, 126 HARV. L. REV. 1838 (2013). The executive orders technically do not apply to independent agencies, but those agencies are informally pressured to comply. Id. at 1839 n.3.

188. Jacob E. Gersen, Legislative Rules Revisited, 74 U. CHI. L. REV. 1705, 1710 (2007) ("The legislative rule label is attractive in the sense that rules issued via notice and comment rulemaking often make new law or establish new policy that has the binding force of law."). For the notoriously complex scholarly debate over the precise contours of the "legislative rules" category, see generally David L. Franklin, Legislative Rules, Nonlegislative Rules, and the Perils of the Short Cut, 120 YALE L.J. 276 (2010); Gerson, supra; John F. Manning, Nonlegislative Rules, 72 GEO. WASH. L. REV. 893 (2004).

189. 5 U.S.C. $\$ 553(\mathrm{~b})(3)(\mathrm{A})$.

190. See generally Nina A. Mendelson, Regulatory Beneficiaries and Informal Agency Policymaking, 92 CORNELL L. REV. 397 (2007) (providing an overview of guidance); Robert A. Anthony, Interpretive Rules, Policy Statements, Guidances, Manuals, and the Like-Should Federal Agencies Use Them to Bind the Public?, 41 DuKE L.J. 1311 (1992) (same).

191. Anthony, supra note 190 , at 1315 . The practical consequence is that, when bringing an enforcement action in court, agencies may invoke violation of a legislative rule as the legal basis for taking action against a regulated party, but may not do the same for nonlegislative rules. 
minor matters of procedure or interpretation, which are interstitial to the more robust legal mandates that are promulgated in statutory provisions or legislative rules.

\section{a. The Formality-Review Tradeoff}

The choice that agencies face when deciding whether to engage in n\&c rulemaking or instead release guidance reflects the formality-review tradeoff. The clearest example concerns the standard of review that applies to agency rules that resolve questions of law. In its influential Mead opinion, ${ }^{192}$ the Supreme Court endorsed the (rough) rule of thumb that agencies' statutory interpretations should receive Chevron deference in connection with judicial review of n\&c rules, ${ }^{193}$ while review of agency guidance should be subject to the much more limited Skidmore standard of deference. ${ }^{194}$ The rule in Mead is subject to many caveats and complications, but the general thrust in this area of the law is that, for pure legal questions, judicial deference is positively correlated with administrative formality. ${ }^{195}$

Another case where the tradeoff arises concerns judicial review of agency actions pursuant to the arbitrary-and-capriciousness $(\mathrm{a} \& \mathrm{c})$ requirement found in Section 706(2)(A) of the APA. ${ }^{196}$ The classic explanation of a\&c review, also known as the "hard look" doctrine, appears in the Court's State Farm opinion, which states that an agency is required to "examine the relevant data and articulate a satisfactory explanation for its action including a 'rational connection between the facts found and the choice made.",197 Although in theory the same a\&c

192. United States v. Mead Corp., 533 U.S. 218 (2001).

193. Id. at 219; Chevron, U.S.A., Inc. v. Nat. Res. Def. Council, Inc., 467 U.S. 837 (1984). The precise meaning of Chevron deference has spawned endless debate, but the basic proposition is that courts must defer to any reasonable interpretation that any agency adopts with regard to ambiguous statutory language. See Matthew C. Stephenson \& Adrian Vermeule, Chevron Has Only One Step, 95 VA. L. REV. 597,597 (2009).

194. Mead, 533 U.S. at 220; Skidmore v. Swift \& Co., 323 U.S. 134, 140 (1944). When applying Skidmore deference, courts need only consult an agency's interpretation to the extent that it is wellreasoned or otherwise persuasive. See Sunstein, supra note 16, at 211.

195. See Barnhart v. Walton, 535 U.S. 212, 222 (2002) (injecting some ambiguity into the Mead precedent); Christensen v. Harris Cty., 529 U.S. 576, 587 (2000) (same). See also generally Lisa Schultz Bressman, How Mead Has Muddled Judicial Review of Agency Action, 58 VAND. L. Rev. 1443 (2005) (examining the effects of Mead and its inconsistent application).

196. 5 U.S.C. $\S 706(2)(A)(2012)$.

197. Motor Vehicles Mfrs. Ass'n, Inc. v. State Farm Mut. Auto. Ins. Co., 463 U.S. 29, 43 (1983) (quoting Burlington Truck Lines v. United States, 371 U.S. 156, 168 (1962)); see also Citizens to Pres. Overton Park, Inc. v. Volpe, 401 U.S. 402, 415-16 (1971), abrogated by Califano v. Sanders, 430 U.S. 99 (1977). 
standard applies to all forms of agency rulemaking, the hard look doctrine indirectly favors legislative over nonlegislative rules. That is because the quasi-procedural nature of the test articulated in State Farm-which demands that agencies "articulate a satisfactory explanation" for their decisions ${ }^{198}$ - maps on to the elaborate reason-giving procedures that are already incorporated in $\mathrm{n} \& \mathrm{c}$ requirements.

Regulatory settlements are less formal than the agency rulemaking process, no matter how it is conducted. The clearest contrast is with n\&c rulemaking. Agencies regularly spend multiple years preparing a single n\&c rule, during which time they produce thousands of pages of documentation that expose the underlying policy rationale to scrutiny from the public, Congress, the executive, and the courts. ${ }^{199}$ Settlements, on the other hand, are crafted through bilateral negotiations between agencies and firms. The substance of those negotiations is kept confidential from the public, and they are conducted without being subject to any APAmandated procedures or systematic oversight by the OMB. ${ }^{200}$ Once deals are struck, they are memorialized by writings that take a variety of formats, but in many cases consist of a handful of pages that cover the barest of factual allegations and assert boilerplate legal conclusions. ${ }^{201}$

Regulatory settlements are less formal than guidance documents as well. For one, the APA calls for certain categories of guidance to be published in the Federal Register. ${ }^{202}$ It also includes a petition procedure that entitles stakeholders to request the "issuance, amendment, or repeal" of any guidance, and requires agencies to provide a reasoned writtenresponse. ${ }^{203}$ Perhaps most important is the relative levels of transparency. Guidance documents necessarily represent an official, explicit statement

198. State Farm, 463 U.S. at 43. Thus, if an identical policy position is expressed in both an n\&c rule and a guidance document, the former is less likely to be vacated on a\&c grounds. See Magill, supra note 16 , at $1390-91$.

199. Cf. Thomas O. McGarity, Some Thoughts on "Deossifying" the Rulemaking Process, 41 DUKE L.J. 1385, 1385-88 (1992) (describing the increase in length of rules and explanations in preparation for judicial scrutiny); Mathew D. McCubbins, Roger G. Noll \& Barry R. Weingast, Administrative Procedures as Instruments of Political Control, 3 J.L. ECON. \& ORG. 243, 254 (1987) (providing an influential theory of the ways that Congress uses administrative procedure to monitor the decision-making process of agencies).

200. But see Farber \& O'Connell, supra note 3, at 1162-63 (speculating that there may be OMB signoff on some settlements).

201. See Koehler, Foreign Corrupt Practices Act Enforcement, supra note 54, at 527-28 (making this point with respect to NPAs and DPAs).

202. 5 U.S.C. § 552(a) (2012) (providing a "publication requirement," which applies to agency guidance that takes the form of interpretive rules or policy statements).

203. Id. at $\S 553$ (e); see Mendelson, supra note 190, at 440-41. It is also common for agencies to voluntarily invite interest groups to consult on informal rules as they are being developed. $I d$. at 428. 
of agency policy. In contrast, the "rule" produced through regulation by settlement is implicit, and consists of the precedential signal that is cobbled together through a body of interrelated settlement agreements. As a result, the policy that is embedded in regulatory settlements is less observable to third parties (and therefore less vulnerable to criticism) ${ }^{204}$

Regulatory settlements are also subject to more limited judicial review than either legislative or nonlegislative rules. The most extreme example is non-prosecution agreements (NPAs), which are concluded through agency "letters" that cannot be challenged in court on any grounds. ${ }^{205}$ With deferred prosecution agreements (DPAs), a charging document is filed in federal court but is accompanied by a settlement agreement, in which the DOJ commits - subject to the court's approval - to withhold trial on the pending charges and to dismiss them completely after a specified period if the defendant corporation complies with certain conditions. ${ }^{206}$ Judicial approval of DPAs is generally a mechanical, automatic process. ${ }^{207}$ In 2015 , when a DPA was rejected by a federal judge for the first time ever, the D.C. Circuit unanimously reversed, explaining that courts have no authority to second-guess the substantive merits of DPAs in any respect, and may only intervene to deter prosecutorial harassment of defendants. ${ }^{208}$

The same general exclusion of meaningful substantive or procedural review also applies to regulatory settlements based on civil claims, which are typically styled as consent orders and filed simultaneously with a civil complaint before a federal court or administrative tribunal. ${ }^{209}$ As with DPAs, the applicable standard of review for civil regulatory settlements was also recently highlighted by an emphatic appellate reprimand - in this instance a unanimous Second Circuit reversal of Judge Rakoff's decision to withhold approval of one of the Securitization Settlements, between the

204. Some suggestive evidence on this point is the DOJ and SEC's apparent reluctance to issue comprehensive guidance on their FCPA enforcement practices, despite being subject to years of questioning over the policy decisions reflected in corporate anti-corruption settlements. See Koehler, Grading the FCPA Guidance, supra note 81, at 1-2.

205. See Garrett, supra note 9, at 924.

206. Id. at 922-24.

207. See U.S. Gov't AcCountability Office, DOJ Has Taken StePs to Better Track Its USE OF DEFERRED AND NON-PROSECUTION AGREEMENTS, BUT SHOULD EVALUATE EFFECTIVENESS 25 (2009), http://www.gao.gov/assets/300/299781.pdf (finding that "judges reported they were generally not involved in the DPA process").

208. United States v. Fokker Servs. B.V., 818 F.3d 733, 741 (D.C. Cir. 2016), rev'g United States v. Fokker Servs. B.V., 79 F. Supp. 3d 160 (D.D.C. 2015); $c f$. United States v. HSBC Bank USA, N.A., No. 12-CR-763, 2013 WL 3306161, at*4-8 (E.D.N.Y. July 1, 2013).

209. See Fokker Servs., 818 F.3d at 743-44 (scope of review is equivalent for consent orders and DPAs). 
SEC and Citigroup. ${ }^{210}$ There, the Second Circuit made clear that civil settlements, including those that seek to further "the public interest" through various forms of injunctive relief, can only be rejected by courts in the event that they fail to meet basic procedural thresholds for legality, intelligibility, or prosecutorial misconduct. ${ }^{211}$ In sum, for all forms of regulatory settlements, regardless of their particular procedural posture, the scope of judicial review is sharply circumscribed relative to any of the standards that are applicable in the rulemaking context.

The formality-review tradeoff holds across different forms of rulemaking. When regulation by settlement is considered alongside n\&c rulemaking and agency guidance, however, it turns out to be both the least formal and least reviewable of all three agency actions. That leads to some curious outcomes in the financial regulation context, where Dodd-Frank has made $\mathrm{n} \& \mathrm{c}$ rulemaking the predominant policymaking tool. ${ }^{212}$ For one, the disparate levels of formality effect the timing of regulation. The SEC concluded its earliest Securitization Settlements before Dodd-Frank was even passed in 2010. Meanwhile, six years later, more than one-fifth of the rulemakings that the SEC is required to issue under Dodd-Frank have yet to be finalized. ${ }^{213}$ Such divergent timelines would make sense if the more deliberative approach taken with rulemaking yielded less ex post scrutiny. Instead, the opposite has occurred. An important SEC rule was struck down by the D.C. Circuit in its Business Roundtable decision, and the U.S. District Court for the District of Columbia has vacated one of the CFTC's rules as well. ${ }^{214}$ By contrast, the Securitization Settlements have been granted perfunctory judicial approval in all but one instance, the

210. SEC v. Citigroup Global Markets, Inc., 752 F.3d 285 (2d. Cir. 2014), vacating and remanding SEC v. Citigroup Global Markets Inc., 827 F. Supp. 2d 328 (S.D.N.Y. 2011).

211. Citigroup, 752 F.3d at 295-97; see also United States v. Microsoft Corp., 56 F.3d 1448, 1460-62 (D.C. Cir. 1995) (holding that the "public interest" criterion does not open up room for substantive judicial review).

212. See Dodd-Frank Progress Report, Fourth Quarter 2014, DAVIS POLK \& WARDWELL LLP 2 (Jan. 1, 2015), https://www.davispolk.com/files/Q4_2014_Dodd-Frank_Progress_Report.PDF (finding that Dodd-Frank mandates that regulatory agencies promulgate roughly 395 new administrative rules).

213. See Ian Cuillerier \& Elizabeth A. Martinez, Implementing Dodd-Frank: Current Status of SEC Mandatory Rulemaking, WHITE \& CASE (Sep. 23, 2016), https://www.whitecase.com/ publications/article/implementing-dodd-frank-current-status-sec-mandatory-rulemaking.

214. Bus. Roundtable v. SEC, 647 F.3d 1144, 1156 (D.C. Cir. 2011) (striking down SEC proxy access rule as arbitrary and capricious); Int'l Swaps \& Derivatives Ass'n v. Commodity Futures Trading Comm'n, 887 F. Supp. 2d 259 (D.D.C. 2012) (striking down a CFTC rule setting position limits on derivatives tied to 28 physical commodities), appeal dismissed, 2013 U.S. App. LEXIS 22618 (D.C. Cir. Nov. 6, 2013); see also Jill E. Fisch, The Long Road Back: Business Roundtable and the Future of SEC Rulemaking, 36 SEATTLE U. L. REV. 695, 704-05 (2013) (analyzing the broader trend of recent "repeated invalidations of SEC rulemakings"). 
Citigroup case, which was quickly reversed upon appeal. ${ }^{215}$ With regulation by settlement, the formality-review tradeoff is turned upside down.

\section{b. The Substance-Discretion Tradeoff}

When agencies undertake rulemaking they are subject to the substance-discretion tradeoff through a number of mechanisms. One of the most direct devices is the Supreme Court's "major questions" doctrine, recently applied in its review of the Affordable Care Act, which stands for the principle that agency statutory interpretations will not receive Chevron deference if they resolve questions of great national importance. ${ }^{216}$ As agencies raise the policy stakes, courts tighten ex post constraints to compensate. Another relevant tool involves statutory provisions that direct agencies to address certain legal issues through n\&c rulemaking, and often further require that those rules be finalized by pre-specified deadlines. That tactic, which Congress used to an unprecedented extent in Dodd-Frank $^{217}$, shuts the door on the opportunity for agencies to rely on guidance to resolve policy decisions that are considered sensitive by Congress.

A more subtle source of the substance-discretion tradeoff arises from the strategic substitution effect: when developing relatively significant or innovative regulatory policies, agencies have an incentive to voluntarily shift from guidance to rulemaking in order to safeguard those decisions with more deferential judicial review. ${ }^{218}$ Less risk-averse agencies, on the other hand, may adopt the opposite strategy, and attempt to rely on guidance as a way to smuggle significant policy decisions under the n\&c radar. ${ }^{219}$ One roadblock that the latter strategy will run into, however, is

215. See Citigroup, 752 F.3d at 289.

216. King v. Burwell, 135 S. Ct. 2480, 2488-89 (2015); see also Util. Air Regulatory Grp. v. EPA, 134 S. Ct. 2427, 2444-46 (2014); FDA v. Brown \& Williamson Tobacco Corp., 529 U.S. 120, 132-33, 159-61 (2000); cf. Sunstein, supra note 16, at 193 (discussing the "major questions" doctrine).

217. Jacob E. Gersen, Administrative Law Goes to Wall Street: The New Administrative Process, 65 ADMIN. L. REV. 689, 724-25 (2013) ("Statutory deadlines are scattered throughout administrative law, but the scope and scale of their use in Dodd-Frank is unheard of.").

218. Stephenson, supra note 17, at 530-31. Empirical studies find that guidance documents usually tackle smaller issues, which suggests that the strategic substitution effect is a pervasive influence. Connor N. Raso, Note, Strategic or Sincere? Analyzing Agency Use of Guidance Documents, 119 YALE L.J. 782, 821-22 (2010).

219. See, e.g., Jennifer Nou, Agency Self-Insulation Under Presidential Review, 126 HARV. L. REV. 1755, 1776-77 (2013); Bryan Clark \& Amanda C. Leiter, Regulatory Hide and Seek: What Agencies Can (and Can't) Do to Limit Judicial Review, 52 B.C. L. REV. 1687, 1692 (2011). 
put in place by executive orders that mandate OIRA review for any agency action that produces a "significant" rule, regardless of whether a rule is nominally packaged as guidance. ${ }^{220}$ A further hurdle is introduced by "procedural review" of guidance, a judicial doctrine that empowers courts to invalidate any agency rule that purports to be nonlegislative guidance but in substance resembles the broad policy positions that are characteristic of legislative rules. ${ }^{221}$ Taken together, this pair of executive and judicial safeguards limits an agency's chances of skirting the substance-discretion tradeoff through the opportunistic use of guidance.

The substance-discretion tradeoff thus permeates the incentives that agencies face when deciding whether to shift between rulemaking forms. Regulation by settlement, by contrast, avoids those same dilemmas in dramatic fashion. As each of the three case studies show, regulatory settlements have been used to establish de facto legal standards that are bolder than what is provided by related statutory or administrative rules: the FCPA Settlements stake out more extreme policy positions than those that are found in the FCPA Guidance, the Securitization Settlements reflect a theory of liability that goes far beyond Dodd-Frank's disclosure and due diligence reforms in the same area, and the Benchmark Settlements impose a broader prohibition on financial market manipulation than was provided in parallel CFTC regulations, both before and after Dodd-Frank. ${ }^{222}$ At the same time, relative to regulatory settlements, agency rulemaking is subject to more intensive oversight on all fronts-from Congress, the courts, the Executive Office of the President, and the public.

A hypothetical comparison between agency guidance and regulatory settlements drives this point home. Assume that the implicit rule created by the Securitization Settlements was instead formulated as a guidance document - call it, the "Securitization Interpretive Rule." Pursuant to the APA, the relevant legal standard would be articulated in express terms (e.g. "banks shall be liable for negligent securitization practices"),

220. A rule will be categorized as "significant" if it estimated to have an "annual effect on the economy of $\$ 100$ million or more" or if it "raise[s] novel legal or policy issues." Exec. Order No. 12866, 58 Fed. Reg. 51,735 (Oct. 4, 1993), supplemented by Exec. Order No. 13563, 76 Fed. Reg. 3821 (Jan. 21, 2011); Exec. Order No. 13422, 72 Fed. Reg. 2763 (Jan. 23, 2007), revoked by Exec. Order 13497, 74 Fed. Reg. 6113 (Jan. 30, 2009); OMB Memorandum M-09-13 on Guidance for Regulatory Review (Mar. 4, 2009), https://obamawhitehouse.archives.gov/sites/default/files/omb/ assets/memoranda_fy2009/m09-13.pdf.

221. The logic is that, once guidance is unmasked as a de facto legislative rule, it automatically follows that it is procedurally defective for failing to comply with the n\&c process. See Seidenfeld, supra note 175; David L. Franklin, Two Cheers for Procedural Review of Guidance Documents, 90 TEX. L. ReV. SeE ALso 111, 120-21 (2012); see, e.g., Appalachian Power Co. v. EPA, 208 F.3d 1015, 1020-21 (D.C. Cir. 2000); Cmty. Nutrition Inst. v. Young, 818 F.2d 943, 945-48 (D.C. Cir. 1987).

222. See supra Section II.B. 
published in the Federal Register, and subject to public petition requests thereafter. The Securitization Interpretive Rule would easily qualify as a "significant" rule- $\$ 50$ billion in settlement penalties satisfies the applicable $\$ 100$ million annual impact requirement for 500 consecutive years - and therefore fall under the executive branch requirements for formal cost-benefit analysis and OIRA review. If it satisfied the OIRA process, the Securitization Interpretive Rule might then face a "procedural review" challenge in federal court, and potentially be vacated on the grounds that it is a defective nonlegislative rule. If the Securitization Interpretive Rule survived procedural review, and was eventually put at issue in a subsequent enforcement action against a regulated party, it would then undergo a second round of judicial scrutiny, pursuant to the a\&c hard look doctrine as well as the minimally deferential Skidmore standard. ${ }^{223}$

There is a strain of administrative law scholarship that regards guidance with suspicion, and the business law literature is even quicker to condemn "regulation by guidance" as an unacceptably informal way to make policy "through the back door."224 But everything is relative. Compared to regulation by settlement, guidance is a staple of the agency policymaking toolkit, is predictably conservative in scope, and is constrained by an array of well-established procedural safeguards.

\section{Adjudication}

Agencies act in an adjudicative capacity when issuing orders that resolve legal questions concerning particularized parties. ${ }^{25}$ Under the Chenery principle, agencies are free to use those same decision-making procedures to announce new policies of general applicability. ${ }^{226}$ Prior to the ascendance of $\mathrm{n} \& \mathrm{c}$ rulemaking, the historical norm was for agencies to develop regulatory rules through adjudicative proceedings, and a few agencies continue to maintain that practice. ${ }^{227}$

223. The latter inquiry in particular would be a hard sell, given the government's lack of success in analogous financial crisis litigations. See supra Section II.B.ii.

224. Peirce, supra note 155, at 22-24 (criticizing CFTC guidance as backdoor policymaking); but cf. Donna M. Nagy, Judicial Reliance on Regulatory Interpretations in SEC No-Action Letters: Current Problems and a Proposed Framework, 83 CORNELL L. REV. 921, 966-95 (1998) (explaining how certain expressions of SEC policy, known as no-action letters, can slip through the procedural cracks that normally govern interpretive statements and other guidance documents).

225. See 5 U.S.C. § 551(7) (2012); see also David L. Shapiro, The Choice of Rulemaking or Adjudication in the Development of Administrative Policy, 78 HARV. L. REV. 921, 924 (1965).

226. SEC v. Chenery Corp., 332 U.S. 194, 208 (1947) (Chenery II); see Shapiro, supra note 225, at $925-27$.

227. See Daniel R. Ernst, TocQueville's Nightmare: The Administrative State EMERGES 
Administrative adjudications are conducted with varying degrees of formality. The APA requires that agencies are required to adopt "formal" adjudicative procedures whenever the applicable organic statute calls for a hearing "on the record." 228 Formal adjudications include oral argument before an independent Administrative Law Judge (ALJ), along with many of the procedural amenities that are attendant to litigation in federal court. ${ }^{229}$ Where an organic statute does not contain the relevant triggering language, the APA allows agencies to engage in "informal" adjudication. ${ }^{230}$ Agencies are free to conduct informal adjudications through as minimal a process as they deem reasonable, ${ }^{231}$ but in practice those proceedings tend to incorporate some form of paper hearing and are resolved by the decision of a neutral Administrative Judge (AJ) (a variant on the ALJ position). ${ }^{232}$

\section{a. The Formality-Review Tradeoff}

Judicial doctrines that govern the formality-review tradeoff in the rulemaking context apply to an agency's choice of formal versus informal adjudications. For questions of law, the Mead rule controls and calls for federal courts to apply Chevron deference to agency statutory interpretations announced in formal adjudications while applying the stricter Skidmore standard in informal adjudications. ${ }^{233}$ "Hard look" a\&c review also applies to all forms of agency adjudication. As in the case of rulemaking, the a\&c standard provides an implicit gradient of deference between formal and informal adjudications due to the more thoroughgoing deliberation that is built into the formal hearing process. The same may

IN AMERICA, 1900-1940 (2014) (tracing formative efforts to constrain the policymaking capacity of agency adjudications). Contemporary adjudication-centric agencies include the National Labor Relations Board, the Bureau of Immigration Affairs, and, to a slightly lesser extent, the Federal Trade Commission. See, e.g., Mark H. Grunewald, The NLRB's First Rulemaking: An Exercise in Pragmatism, 41 DUKE L.J. 274, 274 (1991).

228. 5 U.S.C. $\S 554($ a) (2012)

229. Id. at $\S \S 554,556-58$ (providing procedural requirements for formal adjudications). One major departure from federal trial practice is that hearsay and other exclusionary rules in the Federal Rules of Evidence do not apply in agency adjudications. See generally William H. Kuehnle, Standards of Evidence in Administrative Proceedings, 49 N.Y.L. SCH. L. REV. 829 (2005).

230. 5 U.S.C. $\S 555$.

231. Pension Benefit Guar. Corp. v. LTV Corp., 496 U.S. 633 (1990); see also Vermont Yankee Nuclear Power Corp. v. Nat. Res. Def. Council, 435 U.S. 519 (1978).

232. See Paul Verkuil, A Study of Informal Adjudication Procedures, 43 U. CHI. L. REV. 739, 757-79 (1976). The putative "independence" of ALJs and AJs might seem to limit the policymaking potential of administrative adjudications, but it does not do so in practice because senior agency officials have effectively unlimited discretion to revise the legal conclusions and findings of fact that are contained in an initial adjudicative decision. 5 U.S.C. $\S 557(\mathrm{~b})$.

233. United States v. Mead Corp., 533 U.S. 218, 230-35 (2001). 
also be said of judicial review of agencies' findings of fact, where a nominally distinct pair of standards - "substantial evidence" in formal proceedings; arbitrary-and-capricious review for informal adjudicationsare widely recognized as indistinguishable in practice. ${ }^{234}$ Because the structure of formal adjudications will generate more comprehensive evidentiary records than is the case for informal adjudications, applying a common evidentiary threshold to both procedures leaves the latter on a more secure footing.

Regulatory settlements entail less legal formality than either variety of adjudication. On one level the distinction holds almost as a matter of definition: even the most barebones informal adjudication concludes with a legal determination on the merits, while settlements are quasi-contractual negotiations that result in agreements-not-to-agree. The contrast becomes more concrete with respect to formal adjudications. There, ALJs oversee elaborate adversarial procedures that resemble a full civil trial, and justify the agency's disposition of the case with detailed opinions that are comparable in sophistication to those issued by federal circuit court judges. $^{235}$ A final distinction turns on the publicness of agency adjudication. While settlements are purely bilateral, judicial doctrines have grafted broad intervenor rules onto the APA's requirements for formal adjudications, which facilitates direct stakeholder participation in those proceedings. ${ }^{236}$

The scope of judicial review for regulatory settlements is also narrower than any standard that is applicable to formal or informal agency adjudications, including the substantial evidence test. ${ }^{237}$ The doctrinal differences are not just semantic and can be seen in outcomes. Empirical studies indicate that findings of fact in administrative adjudications are regularly overturned by federal courts. ${ }^{238}$ So too are adjudicative

234. 5 U.S.C. $\$ 706(2)$ (E) (providing the statutory basis for the substantial evidence standard); see Universal Camera Corp. v. NLRB, 340 U.S. 474, 478-79 (1951) (explaining substantial evidence); Ass'n of Data Processing Serv. Orgs. v. Bd. of Governors, 745 F.2d 677, 683-84 (D.C. Cir. 1984) (holding that the two standards are functionally identical).

235. See note 229 and accompanying text. According to one study, the average opinion of SEC ALJs contains a comprehensive recitation of the relevant factual findings, legal analysis and choice of remedy, and is similar in length and complexity to securities law opinions issued in the Second Circuit. See David Zaring, Enforcement Discretion at the SEC, 94 TEX. L. REV. 1155, 1180 (2016).

236. See Magill,supra note 16, at 1398-99, 1433.

237. As the Second Circuit held in reversing Judge Rakoff's rejection of the Citigroup settlement, the legal standard for court approval of an agency settlements does not require those agreements to meet any level of factual sufficiency. See SEC v. Citigroup Global Markets, Inc., 752 F.3d 285, $297-$ 98 (2d Cir. 2014).

238. See Zaring, supra note 174, at 141 (finding that "appellate courts reverse agency formal adjudications of fact slightly more than one third of the time"). 
determinations of law, with a notable recent example being the D.C. Circuit's reversal of a significant adjudicative order issued by DoddFrank's Consumer Financial Protection Bureau. ${ }^{239}$ Thus, administrative adjudication reflects another area of agency policymaking where the formality-review tradeoff holds across both formal and informal procedures but does not reach regulation by settlement, which combines minimal formality with minimal review.

\section{b. The Substance-Discretion Tradeoff}

The most critical decision affecting the mode in which regulatory policy is produced is an agency's choice between rulemaking and adjudication. With the "rulemaking revolution" that took place in the $1960 \mathrm{~s}$ and $70 \mathrm{~s}$, that decision came to reflect the substance-discretion tradeoff operating on an historical scale. During those decades, a confluence of legal and non-legal changes caused agencies to shift to rulemaking as the dominant forum for issuing high-impact policy decisions. ${ }^{240}$ But as substantive policymaking migrated toward rulemaking, the courts improvised a set of constraints to follow. ${ }^{241}$ The result is that, since administrative rules became the engine of executive policymaking, the n\&c process has been "ossified" by the imposition of multi-year procedural hurdles, and the overall equilibrium of agency discretion and constraint remains in place. ${ }^{242}$

The substance-discretion tradeoff can also be seen at work along a number of dimensions with respect to agencies' use of formal versus informal adjudication. First, as a result of the strategic substitution effect, agencies frequently layer procedural formalities onto informal adjudications, although the APA does not require them to do so. ${ }^{243}$ Second, the Supreme Court's caselaw on constitutional due process includes doctrines that require agencies to provide enhanced procedural protections in adjudications where a significant deprivation of liberty or

239. PHH Corp. v. Consumer Fin. Prot. Bureau, 839 F.3d 1 (D.C. Cir. 2016), vacated by PPH Corp. v. Consumer Fin. Prot. Bureau, 2017 U.S. App. LEXIS 2733 (awaiting decision).

240. See Peter L. Strauss, From Expertise to Politics: The Transformation of American Rulemaking, 31 WAKE FOREST L. REV. 745, 755-60 (1996); Reuel E. Schiller, Rulemaking's Promise: Administrative Law and Legal Culture in the 1960s and 1970s, 53 ADMIN. L. REV. 1139, 1143-1155 (2001); J. Skelly Wright, The Courts and the Rulemaking Process: The Limits of Judicial Review, 59 CORNELL L. REV. 375, 375-76 (1974).

241. In particular, a\&c review was re-conceptualized with the hard look doctrine and the APA's $\mathrm{n} \& \mathrm{c}$ provisions were interpreted in a way that gave those requirements surprising teeth. See VERMUELE, LAW's ABNEGATION, supra note 168, at 33.

242. See McGarity, supra note 199.

243. See Verkuil, supra note 232, at 739-42. 
denial of access to important public goods is at stake. ${ }^{244}$ Third, Section 554 of the APA enables Congress to tailor the formality of adjudicative procedures to the significance of a given policy area, by triggering a requirement for formal adjudication whenever a statute supplies the relevant hearing "on the record" language. ${ }^{245}$

With regulation by settlement, agencies have been systematically adopting bolder, more substantive policy positions in regulatory settlements than in adjudications. The case studies reflect a pattern that provides strong evidence on this point. In each case, agencies have largely hesitated to bring claims against individuals (in federal or administrative court) in connection with the same allegations that underpin million or billion dollar settlements with their employer firms; and in the rare instances when the agencies' legal theories do reach adjudication, they are quite often rejected on the merits. ${ }^{246}$ Therefore, relative to agency adjudication, regulation by settlement evades the substance-discretion tradeoff - with less formality, less judicial review, and more progressive policymaking.

The preceding analysis is particularly relevant to financial regulation, where administrative adjudication is making a comeback. Under DoddFrank, administrative courts receive expanded subject matter jurisdiction and remedial authority for certain securities law claims, and the SEC has taken advantage of those reforms by relying more heavily on formal adjudications conducted in-house by its ALJs. ${ }^{247}$ In doing so, the agency has sparked a firestorm of controversy in the business law press and scholarship, where SEC adjudications are characterized as dangerously illegitimate substitutes for litigation in federal court. ${ }^{248}$ These criticisms

244. See generally Mathews v. Eldridge, 424 U.S. 319 (1976); Goldberg v. Kelley, 397 U.S. 254 (1970). The constitutional due process case law can therefore be seen as an analogue to the "major questions" doctrine applied to rulemaking, but with administrative procedure serving as the supplementary constraint rather than heightened judicial review.

245. 5 U.S.C. § 554(a) (2012); cf. Gersen, supra note 217, at 692 (explaining how Congress now drafts statutes to obtain the same control in the rulemaking context).

246. See supra Section II.B.

247. See Dodd-Frank Wall Street Reform and Consumer Protection Act, Pub. L. No. 111-203, § 929P, 124 Stat. 1376, 1862 (2010) (codified as amended at 15 U.S.C. $\S \S 78 u-1,78 u-2,78 \mathrm{u}-3$ ) (expanding adjudicatory jurisdiction over certain securities fraud claims, including insider trading, and increasing limits on the SEC's civil fining penalties).

248. See, e.g., David Bario, As the SEC Brings More Administrative Proceedings, Criticism Grows, AM. LAw. (Feb. 26, 2015), http://www.americanlawyer.com/id=1202718494167/As-theSEC-Brings-More-Administrative-Proceedings-Criticism-Grows; Giles D. Beal IV, Judge, Jury, and Executioner: SEC Administrative Law Judges Post-Dodd Frank, 20 N.C. BANKING INST. 413, 41617 (2016); Gretchen Morgenson, Crying Foul on Plans to Expand the S.E.C. 's In-House Court System, N.Y. Times (June 26, 2015), https://www.nytimes.com/2015/06/28/business/secs-in-house-justiceraises-questions.html. 
reflect a serious confusion over administrative law, as there is nothing irregular or unconstitutional about Dodd-Frank's marginal extension of adjudicative authority for financial regulators. ${ }^{249}$ The controversy itself is instructive, however. As with anxieties about "regulation by guidance," the outcry over SEC adjudication provides another case where an administrative mechanism is perceived to be regulatory discretion run wild, when in fact it fits comfortably within a well-defined network of constraints.

\section{Enforcement}

The APA bifurcates the administrative process into either rulemaking or adjudication, and does not recognize "enforcement" as an equivalent form of agency action. Agencies nonetheless perform an enforcement function, which has distinct legal and conceptual features, and regulatory policy can be influenced by decisions regarding how that function is exercised. ${ }^{250}$ Regulatory settlements are a normal part of the administrative enforcement process but, as will be explained, regulation by settlement as a policymaking technique departs from conventional agency enforcement practices in significant ways.

An agency's ability to initiate enforcement proceedings is determined by its organic statute, which may authorize actions in administrative court, federal court, or both. Where an agency is not entitled to bring a civil enforcement action directly, it can usually refer cases to the DOJ, which may litigate on the agency's behalf. ${ }^{251}$ The internal deliberative process that an agency uses to determine whether to bring an enforcement action is not structured by any APA requirements and, under the Heckler prosecutorial discretion doctrine, those decisions are not reviewable in

249. Agency adjudication is the most historically-entrenched regulatory practice in American government. SEC ALJs render decisions pursuant to elaborate, congressionally-mandated procedures that have been in place unchanged since 1946, and all findings of fact and law in those decisions are reviewable in federal court. See Zaring, supra note 235, at 1197 (making the same general point); but see Gideon Mark, Response: SEC Enforcement Discretion, 94 TEX. L. REV. SEE ALso 261 (2016) (providing a contrary view). Although constitutional challenges to SEC ALJs have very recently yielded a circuit split, neither of those cases stand for the proposition that the Dodd-Frank Act represents an impermissible extension of the SEC's adjudicative authority. Compare Raymond J. Lucia Cos., Inc. v. SEC, 832 F.3d 277 (D.C. Cir. 2016) (rejecting all constitutional challenges), reh'g granted, 2017 WL 2727019 (D.C. Cir. June 26, 2017) (awaiting decision), with Bandimere v. SEC, 844 F.3d 1168 (10th Cir. 2016) (holding that the SEC's procedures for selecting ALJs violates the Appointments Clause).

250. See Kate Andrias, The President's Enforcement Power, 88 N.Y.U. L. Rev. 1031, 1042-45 (2013).

251. See Michael Herz \& Neal Devins, The Consequences of DOJ Control of Litigation on Agencies' Programs, 52 ADMIN. L. REV. 1345, 1345-46 (2000). 
court outside of a few exceptional circumstances. ${ }^{252}$ Once an affirmative decision to enforce has been made, the primary procedural requirement is the "separation of personnel" rule provided in APA Section 554(d), which prohibits certain agency officials from simultaneously prosecuting an enforcement action and adjudicating its merits. ${ }^{253}$

Administrative law scholarship often fails to examine the agency enforcement function in isolation; instead, it tends to collapse enforcement into the adjudication side of the rulemaking versus adjudication paradigm. ${ }^{254}$ For purposes of understanding the constraints on administrative policymaking, that analytical move makes good sense under most circumstances. When narrowly construed, "enforcement" represents an intermediate procedural step - the decision to request that another governmental actor, a federal or administrative judge, consider taking some proposed action. It is therefore not a self-sufficient platform, like rulemaking or adjudication, from which an agency can make binding legal determinations or declare policy positions. From this perspective, there is little need to consider the policymaking dynamics of enforcement because enforcement occupies a pre-policymaking phase in the administrative process. And, once an administrative enforcement proceeding has commenced, the familiar constraints applicable to agency adjudication come into play.

Enforcement also does not pose problems for the standard model of administrative policymaking when it is considered directly. Traditional administrative enforcement is entirely consistent, for example, with the substance-discretion tradeoff. On one hand, the enforcement decision involves less procedural formality or judicial review than rulemaking or adjudication. It therefore represents agency discretion at its high point. On the other hand, an enforcement decision is at best a form of agenda control, ${ }^{255}$ whereby agency personnel can "suggest" that an ALJ or federal judge adopt a new policy direction. That is a non-negligible source of influence, but much less impactful than what can be accomplished through $\mathrm{n} \& \mathrm{c}$ rulemaking or formal adjudication. Thus, enforcement pairs maximal discretion with minimal substance, and the standard equilibrium holds. ${ }^{256}$

252. Heckler v. Chaney, 470 U.S. 821, 837-38 (1985).

253. 5 U.S.C. $§ 554$ (d) (2012). There are exceptions for higher-level agency decision-makers.

254. See Bijal Shah, Uncovering Coordinated Interagency Adjudication, 128 HARV. L. REV. 805, 827-28 (2015) ("[T] here are few (or no) satisfying definitions of agency enforcement that are cleanly divisible from adjudication."); see also Magill, supra note 168.

255. See generally Thomas H. Hammond, Agenda Control, Organizational Structure, and Bureaucratic Politics, 30 AM. J. POL. SCI. 379 (1986).

256. The substance-discretion tradeoff may also apply at the decisional level internal to enforcement: namely, whether to bring an enforcement action before an ALJ or in federal court. The 
Despite enforcement's unassuming role within the broader menu of agency policymaking forms, "regulation by enforcement" is a prominent concept in the securities law scholarship, where the SEC's influence over the law of insider trading is considered a paradigm case of the practice. ${ }^{257}$ Analyses of regulation by enforcement often paint a picture of imbalanced policymaking due to prosecutorial discretion run amok. ${ }^{258}$ A review of the development of insider trading, however, indicates that regulation by enforcement is yet another area where consternation over allegedly deficient administrative procedure is largely misplaced.

The origins of modern insider trading law can be traced to a 1961 adjudicative decision by the SEC, Cady Roberts, which put a creative spin on the leading regulation governing securities fraud known as Rule 10b5. ${ }^{259}$ The particular trading prohibition announced in Cady was officially embraced by the courts in the Second Circuit's Texas Gulf Sulphur decision of $1968 .^{260}$ When the SEC and DOJ began to pursue more expansive enforcement theories in the early 1980s, the Supreme Court reversed those actions with a pair of landmark decisions, Dirks and Chiarella, which comprehensively re-wrote the legal framework for trading liability. ${ }^{261}$ Since then, insider trading law has evolved pursuant to an expansive body of federal common law which has micromanaged the

SEC claims that it takes big, policy-relevant cases to federal court, rather than to ALJs, on the grounds that federal trials provide more procedural formality. Division of Enforcement Approach to Forum Selection in Contested Actions, SEC (2015), https://www.sec.gov/divisions/enforce/enforcementapproach-forum-selection-contested-actions.pdf.

257. See Pitt \& Shapiro, supra note 15, at 155; see also ANTHONY BARKOW \& RACHEL BARKOW, PROSECUTORS IN THE BOARDROOM: USING CRIMINAL LAW TO REGULATE CORPORATE CONDUCT (2011); Roberta S. Karmel, Regulation by Prosecution: The Securities and Exchange Commission vs. Corporate America (1982); James J. Park, The Competing Paradigms of Securities Regulation, 57 DUKE L.J. 625, 635 (2007).

258. A.C. Pritchard, The SEC, Administrative Usurpation, and Insider Trading, 69 STAN. L. REV. ONLINE 55, 60 (2016); Joan MacLeod Heminway, Just Do It! Specific Rulemaking on Materiality Guidance in Insider Trading, 72 LA. L. REV. 999, 1024-25 (2012).

259. In re Cady, Roberts \& Co., No. 8-3925, 1961 WL 59902 (Nov. 8, 1961); Rules and Regulations Under the Securities and Exchange Act of 1934, 17 C.F.R. $\$ 240.10 b-5$ (2015); cf. SEC v. Capital Gains Research Bureau, Inc., 375 U.S. 180, 195 (1963) (affirming SEC policymaking through adjudication, per the Chenery principle).

260. SEC v. Texas Gulf Sulphur Co., 401 F.2d 833, 848 (2d Cir. 1968) (en banc).

261. Chiarella v. United States, 445 U.S. 222 (1980); Dirks v. SEC, 463 U.S. 646 (1983). 
applicable legal standards, ${ }^{262}$ the occasional Congressional intervention, ${ }^{263}$ and SEC rulemakings that are reactive to movements in the case law. ${ }^{264}$

The record reflects that the SEC's enforcement priorities have played a role in insider trading law, but not a role with greater influence than other regulatory tools, and certainly not a role which exceeds that of the courts. The ironic takeaway is that insider trading turns out to be a textbook example of the constrained and multi-faceted nature of administrative lawmaking, rather than a case of single-minded prosecutorial discretion gone wild. ${ }^{265}$ Although a comprehensive review of other areas where agency enforcement strategies play a prominent role in policy development - for example, in antitrust regulation or other parts of securities law-is beyond the scope of this article, the basic lesson provided by insider trading generally holds in those instances as well. ${ }^{266}$ Thus, even during purported episodes of regulation by enforcement, the agency enforcement function represents a relatively conventional form of administrative policymaking.

There are two exceptional cases, however, where enforcement shifts from an orthodox to an unorthodox mode of agency action. One is the

262. See Pritchard, supra note 258 , at 60 ("[T] $]$ he Court has not been satisfied to simply decide the [insider trading] case before it . . [ [and has] ranged widely in defining the law of insider trading."); Heminway, supra note 258 , at 1006-08 (calling the applicable materiality test a "judicially constructed definition"). For the most recent examples, see generally Salman v. United States, 137 S. Ct. 420 (2016); United States. v. Newman, 773 F.3d 438 (2d Cir. 2014); see also Stephen M. Bainbridge, The Law and Economics of Insider Trading: A Comprehensive Primer (2001) (unpublished manuscript), https://papers.ssrn.com/sol3/papers.cfm?abstract_id=261277 (reviewing the evolution of insider trading case law).

263. See Insider Trading and Securities Fraud Enforcement Act of 1988, Pub. L. No. 100-704, 102 Stat. 4677 (1988) (codified as amended at 15 U.S.C. $\$ \S 78 \mathrm{t}-1,78 \mathrm{u}-1,80 \mathrm{~b}-4 \mathrm{a}$ (2012)); Insider Trading Sanctions Act of 1984, Pub. L. No. 98-376, 98 Stat. 1264 (1984) (codified as amended at 15 U.S.C. § 78a). Pritchard, supra note 258, at 62 ("Congress has at least ratified the idea of a common law insider trading prohibition by enacting legislation in 1984 and 1988 ramping up the penalties for insider trading.").

264. The SEC finalized Rule 14e-3 in response to Chiarella and Dirks. Rules and Regulations Under the Securities and Exchange Act of 1934, 17 C.F.R. § 240.14e-3 (2015); 15 U.S.C. § 78n(e) (2012). The SEC's most significant recent policymaking on insider trading consist of a disclosure rule known as “Reg. FD." See 17 C.F.R. $\S \S 243.100-03$ (2015).

265. See Magill, supra note 16, at 1402 n.62 (making this same point).

266. In the antitrust context, see William F. Baxter, Separation of Powers, Prosecutorial Discretion, and the 'Common Law' Nature of Antitrust Law, 60 TEX. L. REV. 661, 686-87 (1982). Another notable episode of enforcement by the SEC took place in the early 2000s, when the agency worked in conjunction with efforts by Eliot Spitzer (then New York's Attorney General) to bring prosecutions against the mutual fund industry. See BARKOW \& BARKOw, supra note 257. The SEC quickly retreated from the more aggressive tactics of that campaign, however, and a combination of regulatory rulemaking, guidance, and judicial review soon occupied the same policy space. See Park, supra note 22, at 154-55; Jonathan R. Macey, State-Federal Relations Post-Eliot Spitzer, 70 BROOK. L. REV. 117, 133 (2004) (arguing that Spitzer's interventions in securities markets represented a "hostile takeover of the SEC," "hijacking its agenda"). 
familiar practice of non-enforcement through agency inaction. ${ }^{267}$ Nonenforcement is able to upset the substance-discretion tradeoff that typically applies to agency enforcement by taking advantage of the agenda control aspect of the enforcement procedure with a highly aggressive strategy of "negative agenda control."268 By systematically excluding critical portions of the regulatory framework from the adjudicative phase where enforcement is given final effect, preexisting policy positions can be negated in a way that amounts to a new round of significant substantive policymaking. Since non-enforcement on such a scale is a fairly extreme measure, the most notable cases of agency inaction are usually the product of presidential high politics, as the marijuana example from the Obama administration suggests. ${ }^{269}$

Regulation by settlement represents a second strategy for destabilizing the standard substance-discretion balance of agency enforcement. With traditional agency enforcement, there may often be high settlement rates of 80 or 90 percent without the settlement process having any real impact on policy. The majority of cases which settle involve cookie-cutter issues that do not raise significant legal questions, and for the minority of enforcement actions that are premised on novel theories, defendants have an incentive to see the dispute through to adjudication on the merits. At that point, agency adjudication becomes the relevant policymaking forum, and the decision to announce progressive policies is up to the ALJ (or federal court judge). This is how insider trading law was launched, by an SEC adjudication that produced the Cady decision. ${ }^{270}$

Regulation by settlement only becomes possible in the post-2000s enforcement landscape, where a number of factors converge to make the settlement of corporate enforcement actions a foregone conclusion. ${ }^{271}$ As a result, enforcement is no longer an intermediate step that allows policies to be proposed to adjudicators. Instead, policymaking decisions occur directly in the enforcement phase, where actions that assert novel legal theories are associated with significant negotiated penalties as a matter of course. Under the conditions just described, settlement may still remain a low-stakes, idiosyncratic process that does not function as a significant

267. See supra note 4.

268. See Gary W. Cox \& Matthew D. McCubbins, Setting the Agenda: Responsible PARTY GOVERNMENT IN THE U.S. HOUSE OF REPRESENTATIVES (2005) (analyzing the negative agenda control concept in the Congressional context).

269. See Markano, supra note 180, at 291. But cf. United States v. Texas, 136 S. Ct. 2271 (2016) (affirming by an equally divided court the Fifth Circuit's decision that rejected Obama administration's non-enforcement of immigration laws).

270. See Cady, Roberts \& Co., No. 8-3925, 1961 WL 59902 (Nov. 8, 1961).

271. See supra Section II.A. 
policymaking vehicle. But regulation by settlement has emerged in recent years because, as the case studies provided above illustrate, agencies have decided to leverage the new dynamics of settlement to the greatest extent possible. ${ }^{272}$ In the process, federal agencies have managed to reshape the nature of financial regulation and administrative policymaking.

\section{NORMATIVE CONSIDERATIONS \& POLICY IMPLICATIONS}

This Section turns to the normative and prescriptive issues that are raised by the positive analysis of regulatory settlements presented above. Part A evaluates the strengths and weaknesses of regulation by settlement as a regulatory tool. Part B reviews the policy debate around regulatory settlements and suggests some limited reforms.

\section{A. Evaluating Regulation by Settlement}

A threshold point when considering the merits of regulation by settlement is that there is nothing inherently problematic about the settlement of legal disputes relative to their resolution on the merits through adjudication. That is not necessarily the consensus view, and there is a long tradition of modest hostility toward settlement in the scholarship. The classic critique by Owen Fiss focused on the fact that settlement denied plaintiffs an opportunity to fully assert their legal rights and foreclosed public articulation of important social values by courts. ${ }^{273}$ More recently, anti-settlement sentiment has been revived and directed at regulatory settlements with a forceful twist. The main concern, voiced most prominently by Judge Rakoff, is that regulatory settlements typical take a "neither-admit-nor-deny" format, which allows defendants to avoid being associated with any official statement of wrongdoing, as would otherwise be forthcoming with a trial verdict or criminal guilty plea. ${ }^{274}$

272. One simple way to appreciate the impact of regulation by settlement is to compare the role of enforcement in the formation of insider trading law and anti-corruption law under the FCPA. In the former case, the SEC and DOJ's enforcement strategies exerted a substantial but far from dominant influence. In the FCPA context, those agencies' enforcement decisions have produced a body of settlements that swallow up the policy space completely.

273. Owen M. Fiss, Against Settlement, 93 YALE L.J. 1073, 1085-86 (1984). For a more recent version, see Dana. A. Remus \& Adam S. Zimmerman, The Corporate Settlement Mill, 101 VA. L. REV. 129, 132 (2015).

274. Rakoff, supra note 28; see Urska Velikonja, Securities Settlements in the Shadows, 126 YALE L.J.F. 124, 129 (2016); Priyah Kaul, Note, Admit or Deny: A Call for Reform of the SEC's “Neither-Admit-Nor-Deny" Policy, 48 U. Mich. J.L. ReForm 535, 537 (2015); Ross MacDonald, Note, Setting Examples, Not Settling: Toward a New SEC Enforcement Paradigm, 91 TEX. L. ReV. 419, 419-20 (2012). 
While the prior critique emphasized judicial affirmance of positive rights, the contemporary argument recasts the point in more punitive terms, and calls for the public acknowledgement of legal culpability.

The classic rebuttal, equally applicable to both critiques, is that the institution of settlement redeems individuals' private right to be free from legal conflict, and promotes the public interest by ensuring efficient administration of the courts (in the context of civil litigation) and by economizing on the scarce enforcement resources of the government (in the context of regulatory actions). ${ }^{275}$ There is also a further weakness specific to Judge Rakoff's line of argument. Any push for admissions of guilt is self-defeating in the current regulatory environment because a defining feature of regulation by settlement is that agencies seek to hold firms liable on an across-the-board, industrywide basis. By definition, such blanket assertions of wrongdoing carry no stigma, no reputational harm, and no negative signal to the market. ${ }^{276}$ This point was made clear by the Benchmark Settlements when guilty pleas were awkwardly shoehorned into certain settlements and investors did not bat an eye. ${ }^{277}$ With regulation by settlement, "a fine is a price"-no matter how it is labelled. ${ }^{278}$ Admissions of wrongdoing will only carry the force that their proponents desire in a much more minimalist, selective enforcement regime.

A second variety of objections centers on the claim that regulatory settlements are contrary to "rule of law" principles, in various ways. ${ }^{279}$ One basic vulnerability of this position is that there is no obvious consensus over what precise, concrete requirements the rule of law entails. ${ }^{280}$ Like "justice," the "rule of law" label is more of a conclusion than a description and can often stand for nothing more than the mix of

275. See generally Samuel Issacharoff \& Robert H. Klonoff, The Public Value of Settlement, 78 FORDHAM L. REV. 1177 (2009) (providing a defense of settlements).

276. See Jonathan R. Macey, The Death of Corporate Reputation: How Integrity Has BEEN DESTROYED ON WALL STREET 235-36 (2013).

277. See Son \& Dexheimer, supra note 140.

278. Uri Gneezy \& Aldo Rustichini, A Fine is a Price, 29 J. Legal StUD. 1, 14 (2000); cf. Daniel R. Fischel \& Alan O. Sykes, Corporate Crime, 25 J. Legal StUd. 319, 321 (1996).

279. Jennifer Arlen, Prosecuting Beyond the Rule of Law: Corporate Mandates Imposed Through Deferred Prosecution Agreements, 8 J. LEgAL ANALYSIS 191, 191 (2016).

280. See Richard H. Fallon, Jr., "The Rule of Law" as a Concept in Constitutional Discourse, 97 Colum. L. REv. 1, 1 (1997) ("Significantly, however, the meaning of the phrase 'the Rule of Law' . . has always been contested."). Debates relating to the rule of law reflect a dilemma that applies to most cases of radical theoretical disagreement, such as those found in moral philosophy: consensus over specific cases cannot be generalized to broader conceptual categories, while agreement on abstract concepts only takes place at a level of specificity that is insufficient to apply them to particular cases. See also Bernard Williams, Ethics AND the Limits of Moral PhilOSOPHY 147-48 (1985). 
legal-political norms that are preferred or simply familiar to the user. That practice is especially problematic in the regulatory settlement context because settled principles of administrative law are often met with extreme skepticism, and perfectly mundane practices-agency adjudication, guidance through non-legislative rules, enforcement of insider tradingare considered exercises in lawlessness. ${ }^{281}$ The general posture of these arguments can be understood as an accidental alliance between a majority of the business law literature on the one hand and an embattled minority of public law scholars on the other, the latter of which deny the legitimacy of the post-New Deal regulatory state as a whole. ${ }^{282}$

Although there is a more charitable reading of the rule of law critique, it runs into even deeper problems. This Article claims that there is an identifiable collection of legal principles that works to constrain most forms of administrative policymaking, but does not apply to regulation by settlement. A plausible implication is that regulatory settlements now present a rare, genuine threat to rule of law values. The issue is that adopting such a view does not end the analysis, because the rule of law is just one good that must be traded off against others. ${ }^{283}$ A wholesale rejection of regulation by settlement is only justified if there are no related benefits that offset the costs of administrative unorthodoxy.

In practice, regulation by settlement involves a number of costs and benefits. One obvious benefit is policy flexibility. Regulation must keep pace with rapidly changing economic conditions, which result not only from technological progress but also from the process of regulatory

281. A common thread in these critiques is the need for government to maintain a separation of powers structure - but the combination of government functions within the executive branch is a premise of the administrative process. See Withrow v. Larkin, 421 U.S. 35, 49-52 (1975); see also Magill, supra note 168.

282. See generally, Philip Hamburger, Is AdMINistrative LAW Unlawful? (2014) (condemning the administrative state in general); RICHARD A. EPSTEIN, THE CLASSICAL LIBERAL CONSTITUTION (2014) (same); Lawson, supra note 165.

283. For example, the regulation of emergencies often requires neglect of standard legal formalities, but that is considered an appropriate and unavoidable cost of exigency. This is exactly what happened during the financial crisis with "regulation by deal." See Davidoff \& Zaring, supra note 6, at 464-65; cf. Adrian Vermeule, Optimal Abuse of Power, 109 Nw. U. L. REV. 673, 675 (2015) (explaining that the optimal incidence of many social problems, including "abuse of power" is not zero). There are prominent philosophical perspectives that are arguably in tension with this view. See JOHN RAWLS, A THEORY OF JUSTICE 42-45, 235-43 (1971) (defending the idea of a social contract that incorporates "lexicographical" preferences, for which the fairness of society's basic institutional and legal structures takes absolute priority over other considerations); RONALD DWORKIN, TAKING RightS SERIOUSLY 6, 10, 432, 434 (1978) (presenting a similar argument in which rights are "trumps"). The American legal system does not tend to adopt the position of Rawls and Dworkin, and allows tradeoffs between rights against other values in most contexts, including Fifth Amendment due process rights. See, e.g., Mathews v. Eldridge, 424 U.S. 319, 332-34 (1976) (laying out a balancing test for procedural due process). 
arbitrage, in which firms find innovative ways to avoid compliance with the current regulatory environment. ${ }^{284}$ Both of these dynamics are at a high point in the financial sector, which is especially adaptive compared to other industries. ${ }^{285}$ Regulation by settlement is uniquely well-suited for these problems, as settlements can be put in place much more quickly than Congressional legislation or agency regulations made through the rulemaking process.

Another advantage of regulation by settlement is that, due to the lack of constraints from other governmental actors, it is a relatively powerful way to leverage agency expertise. With regulatory settlements, agencies can stretch statutory language liberally and are, therefore, not closely bound to Congressional policy judgments. The limited availability of judicial review preserves agency policy decisions against second-guessing by the courts. The confidentiality of settlement negotiations also forecloses significant public scrutiny and popular pressure. ${ }^{286}$ These features appear questionable at first glance, but become assets when effective policy turns on highly technical issues rather than broad value judgments. The historical independence of the Federal Reserve to control monetary policy is perhaps the ultimate example of technocratic autonomy, and the justifications for that arrangement hold true across finance more generally.

Against the benefits of flexibility and expertise, regulation by settlement also presents certain costs. One potential cost arises from the fact that regulatory settlements, even when used in systematic fashion, tend to signal legal standards that have limited specificity. The vagueness of regulation by settlement means that it may leave regulated industries uncertain as to what constitutes legal compliance, and thereby deter otherwise desirable economic activity. At the same time, this point should not be overstated. The rules versus standards literature does not present strong across-the-board conclusions regarding the optimal predictability or specificity of legal rules, and regulations that retain a degree of ambiguity are likely preferable in certain areas, including financial fraud. ${ }^{287}$ In addition, the case studies indicate that agencies are sometimes

284. For a more general argument regarding the "social acceleration of time" phenomenon in advanced capitalist democracies, see SCHEUERMAN, supra note 167.

285. See Merrill, supra note 2, at 190 (noting "quicksilver" aspect of the financial industry); Matthew C. Turk, The Convergence of Insurance with Banking and Securities Industries, and the Limits of Regulatory Arbitrage in Finance, 2015 ColuM. BuS. L. REV. 967, 970-73 (2015).

286. Stewart, supra note 1, at 1687.

287. See Julian J. Z. Polaris, Backstop Ambiguity: A Proposal for Balancing Specificity and Ambiguity in Financial Regulation, 33 YALE L. \& POL'Y REV. 231, 233-34 (2014); cf. Louis Kaplow, A Model of the Optimal Complexity of Legal Rules, 11 J.L. ECON. \& ORG. 150, 150-51 (1995); Colin S. Diver, The Optimal Precision of Administrative Rules, 93 YALE. L.J. 65, 66 (1983). 
able to wring a surprising amount of precision out of settlements: a hospital administrator in Tajikistan is most likely a "foreign official" for purposes of the FCPA.

A greater concern than the verbal specificity of a legal standard is whether the underlying policy it applies is misguided. Regulation by settlement has two features that may bias the policies it produces in a systematic manner. One is the problems raised by multiple enforcers. Particularly in finance, it is increasingly common for several agencies to enter into regulatory settlements with respect to a single firm and course of conduct. That raises the complicated problem of inter-agency coordination. ${ }^{288}$ Even if it is possible for a single agency to identify a socially optimal settlement structure, multi-agency enforcement introduces the subsequent hurdle of aggregation across enforcement actions.

A second source of policy bias relevant to regulation by settlement comes from what are known as public choice or political economy problems - the presence of incentives that reward government actors for departures from impartial, public-regarding decision-making. ${ }^{289}$ Political economy problems are likely to be acute in the context of regulatory settlements, where skyrocketing corporate penalties present opportunities for "for-profit public enforcement" and a general pull towards overdeterrence. ${ }^{290}$ Public choice dynamics appear at multiple levels of the executive hierarchy. First, there is a revolving door for individual regulators, who can obtain career rewards by maximizing enforcement penalties-gaining a reputation for achieving large fines enhances a regulator's exit opportunities by signaling professional aptitude while also growing the market for compliance services. ${ }^{291}$ Second, at the agency

288. See Jody Freeman \& Jim Rossi, Agency Coordination in Shared Regulatory Space, 125 HARV. L. ReV. 1131, 1145-51 (2012); cf. Max Minzner, A Sentencing Commission for the Administrative State?, 103 GEO. L.J. ONLINE 87, 87-88 (2015) (discussing the need for more consistent penalties and suggesting that policies should be coordinated across "sister regulatory agencies").

289. See generally DenNis C. Mueller, Public Choice III (2003), http://catdir.loc.gov/catdir/samples/cam031/2002022287.pdf; DANIEL A. FARBER \& PHILIP P. FRICKEY, LAW AND PUBLIC CHOICE: A CRITICAL INTRODUCTION (1991).

290. Margaret H. Lemos \& Max Minzner, For-Profit Public Enforcement, 127 HARV. L. Rev. 853, 853-57 (2014); see Matthew C. Turk, A Political Economy Approach to Reforming the Foreign Corrupt Practices Act, 33 Nw. J. INT’L L. \& Bus. 325, 345-47 (2013).

291. Wentong Zheng, The Revolving Door, 90 Notre DAME L. Rev. 1265, 1268 (2015). As one example of this dynamic: on the same day that the New York's Department of Financial Services announced a multi-million-dollar ForEx settlement with Barclays, its commissioner announced that he was leaving the public sector to start a consulting firm. Jessica Silver-Greenberg \& Ben Protess, Benjamin Lawsky, Sheriff of Wall Street, Is Taking Off His Badge, N.Y. Times, (May 20, 2015), https://www.nytimes.com/2015/05/21/business/dealbook/benjamin-lawsky-to-step-down-as-new- 
level, there is the classic model of bureaucratic aggrandizement: the larger the bureaucracy the more powerful the bureaucrat. There is some evidence of this model at work in recent regulatory settlements, where agencies inflate annual enforcement statistics and advertise themselves as "profit centers" of the federal government as part of Congressional or executive budget requests. ${ }^{292}$ Lastly, there are public choice problems at the higher levels of the political process that are especially relevant for financial regulation. A common theme at the intersection of political and financial history is that when governments seek out vehicles for wealth redistribution, the banking system often presents a tempting (but ultimately costly) substitute for the tax system. ${ }^{293}$

The preceding discussion has focused on isolating the key concepts and factors that are necessary to consider in evaluating regulation by settlement. It is likely impossible to weigh them collectively in a way that supports a categorical conclusion about the desirability of recent settlement practices one way or the other. The most plausible interpretation is that regulatory settlements can be a quite effective regulatory tool in some contexts but perform poorly in others. It also implies that policy reforms should be incremental, searching for ways to improve the cost-benefit profile of regulatory settlements at the margin.

\section{B. Reforming Regulation by Settlement}

The rise of regulatory settlements has attracted substantial attention and inspired suggestions for a wide variety of policy responses. Although an exhaustive analysis of each proposal is beyond the scope of this Article, the overview that follows identifies the general strengths and weaknesses of existing ideas and recommends some further directions for reform.

A common theme of most commentary is the need to facilitate greater scrutiny of the settlement process. The preferred mechanism to do so varies, but some popular options can be canvassed briefly. The most straightforward proposal is for federal judges to unilaterally assert more stringent standards of judicial review for settlements, as exemplified by

\footnotetext{
yorks-top-financial-regulator.html?mcubz $=0$.

292. See Velikonja, supra note 44, at 906.

293. See generally Charles W. Calomiris \& Stephen H. Haber, Fragile by Design: The Political Origins of BANKIng CRISIS \& SCARCE Credit (2014); cf. Andy Koenig, Look Who's Getting that Bank Settlement Cash, WAll. ST. J. (Aug. 28, 2016, 5:53 PM), https://www.wsj.com/articles/look-whos-getting-that-bank-settlement-cash-1472421204 (detailing how a significant portion of proceeds from the Securitization Settlements and Mortgage Servicing Settlements have been channeled to politically connected groups, rather than the U.S. Treasury).
} 
Judge Rakoff's Citigroup decision. ${ }^{294}$ An alternative approach would rely on Congressional intervention, through legislation that expressly provides an enhanced judicial review mechanism. ${ }^{295}$ Another legislative remedy already proceeding through Congress is the "Truth in Settlements Act," which requires greater public disclosure of the terms in regulatory settlements. ${ }^{296}$ Other proposals turn to the agencies themselves. One influential idea is for the DOJ to adopt guidelines that standardize the negotiating process for PDAs. ${ }^{297}$ The scholarship has also recommended that agencies make the settlement process more transparent and participatory by conducting public hearings prior to finalizing terms. ${ }^{298}$

The proposals outlined above each raise particularized difficulties, but in the context of regulation by settlement they share one common conceptual shortcoming: they are all premised on oversight mechanisms that would examine individual settlements in isolation. There is a quality control orientation to these approaches which assumes that the relevant policy problem is to encourage best practices through procedures that deter or otherwise weed out ill-advised settlement terms (or entire agreements). That assumption may be unproblematic in a traditional criminal law context, where outlier conduct by a limited group of rogue prosecutors is a major source of policy dysfunction, but it fits poorly with the current corporate enforcement environment, where settlements tend towards boilerplate and uniformity has, if anything, gone to extremes.

A good example is the Swiss Bank Settlements, which involved the DOJ concluding over 70 PDAs within a two-year period. The terms in those agreements do not vary widely, or at all. The urgent question raised by that episode is not whether "PDA \#47" has flouted a guideline or can survive the rigors of a public hearing or pass the eye test of a randomly assigned federal judge. Rather, what is at stake is whether the entire, programmatic imposition of liability has a sound policy rationale when considered as a whole: what its implications are for the structure of the international banking system; whether it will have a positive or negative impact on systemic financial risks; how other financial institutions around

294. See SEC v. Citigroup Glob. Mkts., Inc., 752 F.3d 285 (2d Cir. 2014), vacating and remanding SEC v. Citigroup Glob. Mkts., Inc., 827 F. Supp. 2d 328 (S.D.N.Y. 2011).

295. See Brandon L. Garrett, The Corporate Criminal as Scapegoat, 101 VA. L. REV. 1789, 1842-44 (2015).

296. Truth in Settlements Act of 2015, S. 1109, 114th Cong. (as passed by Senate, Sept. 21, 2015).

297. See Arlen, supra note 279, at 200; cf. Brandon L. Garrett, Structural Reform Prosecution, 93 VA. L. REV. 853, 893 (2007) (“[N]o DOJ guidelines define what remedies prosecutors should seek when they negotiate structural reform agreements.").

298. See Velikonja, supra note 44, at 974-76. 
the world will interpret its significance as regulatory precedent, and what actions they may take in response; the reaction in various international markets; and so on. The underlying point is that the conventional logic of dispute resolution does not apply to regulation by settlement which verges on macroeconomic policy in its scale. Therefore, reforms that would supply a useful source of procedural regularity in prior eras will not address contemporary regulatory dilemmas.

A distinct reform strategy that has been put forward seeks to assess regulatory settlements at a more aggregate level. The ideas in this area build off of the "presidential administration" ${ }^{299}$ motif that originated in the rulemaking context and look for ways to develop more sophisticated procedures for centralized oversight of administrative enforcement (and adjudication) practices within the executive branch. ${ }^{300}$ The Obama administration already took a significant first step in this direction by issuing its "Memorandum on Regulatory Compliance" in 2011. ${ }^{301}$ That document directs agencies to compile enforcement data in a transparent and accessible format so that comparisons can more easily be made across agencies. The overall goal is information-sharing as a means to facilitate inter-agency coordination. The presidential administration proposals aim to deepen that general strategy, primarily by institutionalizing the enforcement oversight function within the OMB, as part of OIRA or with a new equivalent body. ${ }^{302}$

Enhancing the executive branch infrastructure to allow for holistic oversight of administrative enforcement is the most promising measure that has been advocated for managing the future development of regulatory settlements. It addresses the one of the core challenges posed by regulation by settlement - the need for inter-agency coordination - and reflects a response to the increasingly interrelated structure of regulatory settlements. In addition to the steps detailed in existing proposals, two further procedures could be adopted that would complement the broader undertaking of executive review.

First, because large regulatory settlements are so concentrated in the financial sector, information should be aggregated that specifically analyzes agreements in that policy area. Once compiled, that data could then serve as the basis for an impact report or equivalent analysis, prepared

\footnotetext{
299. See Kagan, supra note 13, at 2246; Lessig \& Sunstein, supra note 13, at 2.

300. See Andrias, supra note 250, at 1101-07; Shah, supra note 254, at 858-81; see generally Nicholas Bagley \& Richard L. Revesz, Centralized Oversight of the Regulatory State, 106 COLuM. L. REV. 1260, 1264 (2006).

301. Regulatory Compliance, 76 Fed. Reg. 3825 (Jan. 18, 2011).

302. Andrias, supra note 250, at 1074-1101.
} 
by the Office of Financial Research (OFR) for the Financial Services Oversight Committee (FSOC). ${ }^{303}$ The purpose of the report would be to evaluate how recent enforcement activity interacts with other aspects of the regulatory framework under Dodd-Frank, and the extent to which it raises issues relating to the broader stability and efficiency of the financial sector.

Second, the individual agencies responsible for financial regulation should modify their current practices regarding the reporting of enforcement activity. The annual enforcement summaries of agencies such as the SEC and CFTC currently read like giddy recaps of a highly successful fundraising drive. ${ }^{304}$ The most appropriate interpretation of regulation by settlement, however, is that enforcement essentially functions as an implicit rulemaking process and serves as a boundary marker for sound industry practices. In other words, enforcement is now predominantly a regulatory device, not a backstop against outlawry. There should therefore be some annual accounting of enforcement activity by financial agencies that treats aggregate dollar penalties collected as a policy variable to be optimized in light of related factors, rather than a metric of success. ${ }^{305}$

To summarize, the current regulatory enforcement environment is complex and not amenable to grand over-arching reforms. At the same time, two high level principles should guide policy adjustments in this area. First, reform must shift from procedures that seek to manicure settlements at an individual level to procedures that seek to take a more systemic view that focus on broader patterns of enforcement. Second, as part of the process of developing centralized executive branch oversight of enforcement patterns, there is value-added in concentrating those efforts on agencies responsible for financial regulation and facilitating an active role in that process by entities that Dodd-Frank has established for systemic monitoring of the financial sector.

303. The FSOC was established by Dodd-Frank with the specific purposes of filling a previous gap in the regulatory architecture, which had no one central body responsible for monitoring the banking system from a global perspective. The OFR is also a creation of Dodd-Frank, and functions as a research arm of the FSOC. Dodd-Frank Wall Street Reform and Consumer Protection Act, Pub. L. No. 111-203 $\S 111(b), 152,124$ Stat. 1376, 1392, 1413 (2010) (codified at 12 U.S.C. $\S \S 5321$, 5342) (establishing FSOC and OFR, respectively); see also Eugene A. Ludwig, Assessment of DoddFrank Financial Regulatory Reform: Strengths, Challenges, and Opportunities for a Stronger Regulatory System, 29 YALE J. ON REG. 181, 184 (2012) ("Conceptually, the single greatest advancement of Dodd-Frank is the creation of the OFR.").

304. See, e.g., CFTC Annual Enforcement Results, Fiscal Year 2015, supra note 44.

305. An equivalent to the current state of affairs among financial regulators would be reports by OSHA or the EPA that intentionally inflate and highlight the compliance costs that those agencies' regulations impose on businesses. 


\section{CONCLUSION}

This Article examines the evolution of enforcement settlements between federal regulators and firms. It argues that the increased scale and innovative legal form that those practices have taken amounts to a novel regime of regulation by settlement, with significant implications for scholarship on both financial regulation and administrative law. The legal framework that has been developed to govern the post-crisis financial system is not just a product of Dodd-Frank as is conventionally assumed. Instead, rules established under that regulatory infrastructure sit alongside a substantial body of implicit legal standards that have been promulgated through the precedential signal set by regulatory settlements, which agencies have used in a systematic fashion to target certain areas of the financial sector. A new genre of administrative policymaking has emerged in the process. By removing nearly all the legal constraints familiar to conventional forms of agency action, regulation by settlement has an unruliness reminiscent of administration during periods of emergency, and other unorthodox styles of executive policymaking. Financial regulation is an historical and institutional centerpiece of administrative law, yet existing legal scholarship largely fails to explore the intersection of those two fields. The broader contribution of this Article is to bridge that gap in the literature by analyzing the business law and public law aspects of the regulatory process in conjunction. 